\title{
Informality and Gender in Latin America
}

\author{
Working Paper No 60
}

\section{María Elena Valenzuela}

\section{Policy Integration Department \\ International Labour Office \\ Geneva}

August 2005

Working papers are preliminary documents circulated to stimulate discussion and obtain comments 
Copyright $@$ International Labour Organization 2005

Publications of the International Labour Office enjoy copyright under Protocol 2 of the Universal Copyright Convention. Nevertheless, short excerpts from them may be reproduced without authorization, on condition that the source is indicated. For rights of reproduction or translation, application should be made to the Publications Bureau (Rights and Permissions), International Labour Office, CH-1211 Geneva 22, Switzerland. The International Labour Office welcomes such applications.

Libraries, institutions and other users registered in the United Kingdom with the Copyright Licensing Agency, 90 Tottenham Court Road, London W1T 4LP [Fax: (+44) (0)20 7631 5500; email: cla@cla.co.uk], in the United States with the Copyright Clearance Center, 222 Rosewood Drive, Danvers, MA 01923 [Fax: (+1) (978) 750 4470; email: info@copyright.com] or in other countries with associated Reproduction Rights Organizations, may make photocopies in accordance with the licences issued to them for this purpose.

ISBN 92-2-118048-4 (printed version)

92-2-118049-2 (web version)

First published 2005

Cover:

The designations employed in ILO publications, which are in conformity with United Nations practice, and the presentation of material therein do not imply the expression of any opinion whatsoever on the part of the International Labour Office concerning the legal status of any country, area or territory or of its authorities, or concerning the delimitation of its frontiers.

The responsibility for opinions expressed in signed articles, studies and other contributions rests solely with their authors, and publication does not constitute an endorsement by the International Labour Office of the opinions expressed in them.

Reference to names of firms and commercial products and processes does not imply their endorsement by the International Labour Office, and any failure to mention a particular firm, commercial product or process is not a sign of disapproval.

ILO publications can be obtained through major booksellers or ILO local offices in many countries, or direct from ILO Publications, International Labour Office, $\mathrm{CH}-1211$ Geneva 22, Switzerland. Catalogues or lists of new publications are available free of charge from the above address, or by email: pubvente@ilo.org

Visit our website: www.ilo.org/publns 


\section{Informality and Gender in Latin America}

\section{Contents}

Preface

Introduction

1. Informal Economy and micro-enterprise: concepts and measurements

2. The Growing importance of the informal economy in Latin America.............................. 5

2.1 Countries with high microenterprise employment, especially self-employed workers 9

2.2 Countries with a mixed microenterprise sector, where the self-employed and microenterprises co-exist

2.3 Countries with a small but more developed microenterprise sector ............................. 10

$2.4 \quad$ Women under represented in the microenterprise sector.............................................. 11

2.4.1 Women concentrated in the most precarious sectors: self-employed and unremunerated family members

2.4.2 Male predominance in microenterprises............................................................ 15

2.5 Women concentrate in a few sectors of activity ...................................................... 17

2.6 Enormous income inequalities by sex in the microenterprise sector ............................ 20

2.6.1 Poverty is greatest in the informal sector.............................................................. 24

2.7 Self-employed women workers: shorter hours than microbusiness employers ............. 27

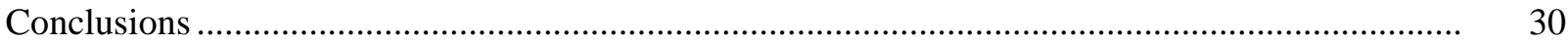

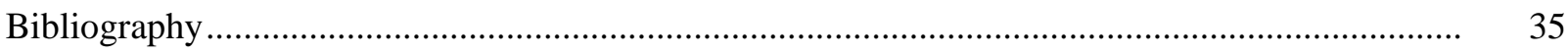




\title{
Preface
}

Informality has been a topic of interest in Latin America for decades. Only more recently, however, has its important gender dimension been more deeply explored. This Working Paper makes a valuable contribution to the debate over informality, which is seen alternatively as an opportunity for promising business start-ups and a poverty trap. With the spotlight on microenterprises, the authors' insights reveal a more complex reality with important gender differences.

The author finds that microbusinesses reflect the gender picture in society and the economy as a whole. At one end of the spectrum are people with skills in market niches that successfully link to the global economy. At the other end are the uneducated who operate on a small, survivalist scale as, for instance, street vendors of imported products. This gap illustrates the critical role played by skills in achieving the gender equality and poverty reduction objectives under the Millennium Development Goals.

At the same time, important differences in the income of families in which a woman member is in the informal economy in various capacities self-employed, employer, etc.) are examined. So too are differences in working hours.

Based on her analysis, the author suggests policy responses to address the different situations. They highlight the need for an integrated package that cuts across the Decent Work Agenda: jobs and incomes, rights, social protection and representation as the basis for social dialogue.

The publication of this Working Paper forms part of the follow-up given by the International Labour Office to the conclusions on decent work and the informal economy, adopted by the International Labour Conference in 2002 (International Labour Conference, 90 ${ }^{\text {th }}$ Session, Record of Proceedings, Provisional Record, No. 25, 2002).

Written in Spanish, the Working Paper was translated by Lake Sagaris. Like other Working Papers, this one is intended to stimulate debate. Comments are welcome at integration@ilo.org.

\author{
Anne Trebilcock \\ Director ad interim \\ Policy Integration Department \\ International Labour Office
}

August 2005 



\section{Introduction $^{1}$}

The activities and number of those employed in the informal economy are growing in Latin America as they are in most of the world, including industrialized countries. Treated for a while as a temporary or marginal phenomenon that would tend to disappear with economic growth, today there is consensus about the importance of the informal economy and its projection over time. In Latin America it accounts for a significant share of employment, contributes substantially to output, and its links to other, more structured and dynamic economic sectors are on the rise. Its composition varies widely and it concentrates a high proportion of insecure, unprotected and poorly paid jobs.

Many women have joined the informal economy in recent decades, in unprotected jobs located in a grey area of "false independence", as well as diverse forms of selfemployment and independent employment, and even as owners of microbusinesses. This situation has led analysts to pay more attention to the changes caused by women's growing participation in this sphere. However, some aspects of the job market remain relatively unexplored and there is still much to be discovered in terms of how the gender variable may affect the performance of women-run businesses, including those operating on a smaller scale or more informally, the area explored by this study.

The dynamics of the informal economy are strongly influenced by gender relationships. Women develop a significant share of informal activities in areas that essentially extend women's domestic roles into the market place, and their performance is marked by occupational segmentation, the fact that their work is chronically undervalued, and their lack of access to and control over productive resources. Women's chances of establishing a business, along with the solidity of the foundations on which it may be based, are also determined by the way property, land ownership, productive capital and equity in general are distributed among men and women. Women's economic base is generally smaller than that of men, restricting the size of business with which they can start and making it difficult even to set one up.

The gender-related inequality and discrimination facing women leads to lower participation rates in the labour force. Cultural factors determining women's roles in society and how well they can combine participation in the labour force and family life also influence their chances of accumulating and generating their own equity, and limit their ability to start and maintain an independent economic initiative. Moreover, their income is lower than men's, their work is less protected, and they are concentrated in occupational niches offering the fewest opportunities to organize and represent their own interests.

All these reasons explain the importance of studying the conditions facing women in the informal economy, particularly those working in the self-employed, very small scale business segments, which are the focus for the analysis in this study. This paper examines how men's and women's behaviour differs and tries to identify the mechanisms by which these differences become gender disadvantages. The analysis is based on data for six of the region's countries: Argentina, Chile, Colombia, Ecuador, Mexico and Peru, which represent the diverse intensity and complexity of informality in Latin America. Where the information available allows it, this study also examines regional averages. In the pages that follow, there is a review of how informality has evolved in the past decade, in terms of the amount and quality of employment generated, the sectors of activity in which it is

\footnotetext{
${ }^{1}$ The author is grateful to Gerhard Reinecke, employment specialist in the ILO Subregional Office of the Southern Cone, Santiago, Chile, for his advice, Veronica Lillo for her help with data processing, and Carolina Préndez for her editorial assistance.
} 
concentrated, income levels and the incidence of poverty among independent workers, business people and wage-earners, and the changes taking place in its internal dynamics as a result of the economic context, seeking to identify the opportunities that open up to women to develop their own autonomous work activity, along with the barriers associated with their gender.

This study is based on data from employment surveys in the respective countries. These offer a profile of each country's reality and make it possible to compare between countries and by sex. However, by its very nature this data does not provide more qualitative information about motives and specific ways that women move into the business sphere, the impact this form of economic participation has on the household, its effects on family organization and women's personal autonomy. All these issues remain open to future reflection.

\section{Informal economy and micro-enterprise: concepts and measurements}

In the literature on the labour market in Latin America it is common to find the concept "informal sector" used extensively. Although the term was coined early in the 1960s in Africa and not in Latin America, a goodly part of the development and debate around this issue has taken place in this region. ${ }^{2}$ The term made it possible to recognize the existence of a sector that included marginal economic activities, but also profitable, efficient companies, despite the fact they functioned beyond the limit of countries' regulations and standards. Broad segments of workers, most of them poor, developed skills or tasks in small scale businesses in order to survive and most of these were neither recognized nor registered. Thus, the first studies of this area of the economy treated them as something that would tend to disappear and integrate into more modern formal sectors, in a process driven by pro-development policies.

Informality has generated debates among supporters of different approaches that have contributed to its characterization and the political agenda arising therefrom. The structural excess labour approach, most developed by the Regional Employment Programme for Latin America and the Caribbean (PREALC), argues that the informal sector reflects the phenomenon of excess labour, which migrates from country to city where it finds no employment in the modern or formal sector, and therefore adopts the self-employment strategy or works in low productivity activities. From this perspective, a distinctive feature of the informal sector is its low endowment of capital and therefore a low capital/labour ratio, low entry barriers in terms of qualifications and capital, its small scale of production (both in volume of sales and number of workers), the extensive presence of activities involving a single individual, operations in competitive markets with precarious access to governmental support mechanisms, and limited capacity for accumulation. Although the unit of analysis is the establishment, this concept is also applied using occupational categories, assimilating the informal sector to self-employment (excluding professionals and technicians) and non-remunerated family members, with those employed in microbusinesses (owners and employees) and domestic service included later.

\footnotetext{
${ }^{2}$ In this sense, see a history of the concept in Bangasser (2000) and the extensive literature prepared by the Regional Employment Programme for Latin America and the Caribbean (Programa Regional del Empleo para América Latina y el Caribe, PREALC), of the World Employment Programme in the International Labour Office (ILO), a pioneer in Latin America in studies of informality, including those by Tokman (1992), Klein and Tokman (1996).
} 
A second approach, whose main proponent is Hernando de Soto (1987), identifies the informal sector as a set of extralegal economic activities, including both productions for the market and for subsistence. The main characteristic for inclusion in the sector is compliance or incompliance with legal requirements, independently of technological factors, the size of units or market relations. Its origin does not lie in labour market dynamics but rather excessive governmental regulation, which triggers a popular response that attempts to break through these legal barriers. The informal producer is not necessarily a low-productivity marginal producer, but rather an entrepreneur who survives or even progresses despite governmental restrictions. The concept is applied by measuring extralegal economic activities, which include a very wide range of individuals, companies and subsistence activities.

A third approach that has influenced debate in the region takes up contributions from authors such as Portes, Castells and Benton (1989) and refers to informality as an unregulated labour market. Defined as the set of income generating activities not regulated by the State - in a social environment where other, similar activities are regulated proponents of this position argue that this occurs to reduce costs, by evading administrative obligations arising from property rights and commercial licenses, as well as legal obligations governing labour contracts and social security systems. Moreover, they place this sector on the same level as accumulation processes on a global scale, arguing that decentralization makes it possible to expand profit margins and that these workers are really disguised wage earners. This approach borrows from the two described above, placing the origin of the informal sector in the structural excess of labour, but defining it in terms of its relationship with the State. Unlike PREALC's approach, however, the sector is defined as an integral part of the modern economy and, unlike Soto, it is treated as part of the normal functioning of capitalism. As a result, informality is not perceived as a phenomenon limited to peripheral economies, but rather is also present in developed economies. This approach is applied by measuring the labour force not covered by the labour legislation, while other authors approximate it using the occupational category, specifically self-employed workers, unremunerated relatives and those working for microbusinesses.

Although these three approaches have achieved some consensus in different spheres, important differences remain and to this day the debate persists between structuralist and neo-liberal currents. ${ }^{3}$ As a way of progressing in this area, in 1993 the $15^{\text {th }}$ International Conference of Labour Statisticians agreed on an operational definition for the informal sector ${ }^{4}$ defining it in terms of company characteristics (production units) where activities take place and not based on the characteristics of the people involved or their occupations. In this sense, the informal sector was defined as a subset of family firms, which do not legally separate household and economic activity, and have no accounting systems to clearly differentiate company activity from that of the owners. Moreover, the conference recommended applying three criteria to define the sector's limits. First, the fact that these companies are unregistered, since they do not comply with national legislation establishing the commercial, tax and other regulations governing businesses. Second, their small size in terms of the employment generated, that is the number of employees permanently employed by the company. Third, the lack of a registry of employees, that is incompliance with labour regulations in terms of social protection and legal standards that should cover them because of their employment. The conference excluded domestic service in its

\footnotetext{
${ }^{3}$ See Tokman (2004) for an analysis of the main points in this debate.

${ }^{4}$ According to Hussmanns (2001), a second objective for advancing toward the application of this concept was to facilitate its inclusion within national accounts systems, to be able to quantify the informal sector's contribution to national economies.
} 
operational definition of the informal sector, leaving a decision on this aspect and the cut off line separating formal from informal businesses to individual countries.

The debate about the ongoing usefulness of this concept, given the speed of economic changes that were erasing the borderline between the two sectors, began before the Labour Statistics Conference officially began to use the term. As a result of simultaneous processes of globalization, productive restructuring and changes in the organization of work, the formal sector had become increasingly informal, while the informal sector was becoming more formal. The informal sector's productive units were adapting to new circumstances, establishing production, commercial and service links with formal sector national and international companies, while formal sector firms tended to respond to pressures to boost international competitiveness due to increasingly open borders by seeking new labour arrangements, among other adjustment strategies. As a result of this last process, employment has become less formal and atypical, precarious and irregular labour relationships have increased, as have diverse forms of sub-contracting, generating a wave of "informal" employees associated with formal companies.

To reflect on the complexities of this phenomenon, the $90^{\text {th }}$ International Labour Conference in 2002 decided to use the concept "informal economy", instead of "sector", to refer to the increasingly large group of employees and companies, both urban and rural, active in the informal sphere, emphasizing the vulnerable nature of their participation in the labour force and/or economic activity (ILO, 2002b). To capture this phenomenon, Hussmanns (2001) proposed using a type of classification involving cross-referencing to combine the different approaches to informality: one based on the characteristics of the productive units where activities occur (focusing on the companies that give rise to the informal sector) and another based on the nature of the employment they generate (focusing on the jobs that give rise to informal employment).

The virtue of this perspective is that it makes it possible to analyze the phenomenon of informality while visualizing both dimensions at the same time, as complementary, rather than alternative views, using a double-entry matrix that identifies the crossovers between the business and labour dimensions. ${ }^{5}$ This matrix also offers a possible framework for mapping the informal economy, since it relates the statistical concept of "employment in the informal sector" with the broader one of informal employment. It also combines three kinds of productive unit (formal sector company, informal sector company and households) and five types of jobs that can be generated within it (independent workers, employers, auxiliary family employees, wage-earners, and members of production-oriented cooperatives).

Using this matrix, several relevant categories arise for analysing the informal economy: auxiliary family employees (with no contract, legal or social protection, in formal or informal companies); wage-earners (with jobs covered by social protection in formal or informal companies, including remunerated domestic service); independent workers (employed by informal companies, including those producing goods for final use in households); employers of informal companies; members of cooperatives of informal producers (ILO, 2002b). Today, however, there are few countries able to fill in this matrix, since labour statistics systems, based on household surveys in most countries, do not provide information on company's characteristics and the jobs they generate at one and the same time.

The application of these new criteria for defining the informal economy can lead to revaluating its weight within national economies and the relevance of existing policies. It is likely that a significant percentage of workers that today appear to belong in the formal

\footnotetext{
${ }^{5}$ See Tokman (2004), for a critical view of the new characterization of the informal economy.
} 
sector (working in companies with more than six employees) are actually employed in the informal sector, since they are not registered with or covered by social security. Similarly, it is possible that some wage-earners who currently appear in the informal sector actually meet the requirements for belonging to the formal sector. This would be the case with microbusinesses that respect regulations, which should be considered formal and receive a different kind of support from informal firms.

From a gender perspective, it has been noted that women's overrepresentation in the informal economy reflects their disadvantages when it comes to participating in the labour market. Women form a large majority of those working in the most precarious segments of the informal economy, such as domestic service and the unremunerated family members' category. These are groups with the lowest income, least protection and least chance of organizing and representing their own interests. Including domestic service as part of the informal sector has nonetheless generated enormous controversy and no consensus has been reached. This issue has not been resolved in attempts to rethink the informal economy, either. One major difference between work in domestic service and the different kinds of self-employment that mainly characterize the informal economy is that in the case of the former, these are workers receiving a fixed (normally very low) wage, working long hours under the supervision of an employer. They have no capital or machinery and lack any link with microbusiness activity. When only segments associated with microbusiness are included, the phenomenon of women's overrepresentation is reversed, since men account for a larger percentage of the labour force than women.

\section{The Growing importance of the Informal Economy in Latin America}

Latin America faces the start of the $21^{\text {st }}$ century with a rise in the precariousness of work: unemployment has risen, social security coverage has fallen, and the number of people employed in lower productivity segments has risen. Some changes in the world of work during the 1990s and a combination of external factors, such as the slowdown of the world's more industrialized economies, the decline in the prices for some of the region's main commodity exports, and the recession that affected some countries (ILO, 2002a) have all influenced this phenomenon. These effects have been magnified by a strong rise in the working age population (2.4\% annually) and women's participation (rising $3.7 \%$ annually, in contrast to a gradual decline in men's). Because of this, the labour force has grown substantially (2.6\% annually), at an even faster rate than the working age population (Economic Commission for Latin America and the Caribbean, ECLAC, 2001).

Growth in the supply of labour has overwhelmed the ability of the region's economies to create jobs. On average, employment rose a low $2.2 \%$ on average from 1990 to 2000. As a result, there was a substantial rise in unemployment among both sexes, but mainly women, expanding the unemployment gap by sex (Abramo and Valenzuela, 2001).

Faced with the lack of jobs, both men and women resorted primarily to self-employment and new jobs were also created in microbusinesses. As a result, the region's employment structure also changed, with informality's weight within the whole rising, while the public sector and jobs in small, medium and large private firms all declined. Using the most traditional definition, ${ }^{6}$ in 2003 the informal economy accounted for $46.7 \%$ of urban employment in Latin America, that is 3.9 percentage points more than in 1990. The

\footnotetext{
${ }^{6}$ The Panorama Laboral de América Latina (Latin America Labour Overview), published by the ILO's Regional Office, includes independent workers in the informal sector, specifically unremunerated family members, those employed in establishments with up to five employees, and those in domestic service, excluding professionals and technicians.
} 
percentage of women $(50.1 \%)$ is more than men $(44.1 \%)$ and could be even higher, if activities for their own consumption were also registered (ILO, 2003). ${ }^{7}$ However, men's and women's participation is very different within the diverse categories that form the informal economy. While men are overrepresented among microbusiness owners and wage-earners, women are the vast majority in domestic service and among unremunerated family members. Because of this, focusing the analysis on the segment of the informal economy formed by microbusinesses and independent workers significantly reduces the importance of women's employment and men are the majority.

In 2003, 39.7\% of urban jobs in Latin America were generated by self-employment and microbusiness (from now on, this is referred to as the microbusiness or microenterprise sector, MS), which rose 2.8 percentage points over 1990. As the percentage of jobs in this sector rose, indicators for social security coverage fell, both for wage-earners in the MS and those working for larger firms. The high correlations between employment in this sector and the precariousness of the labour market make it possible to interpret these figures as an index of the poor quality of employment prevailing in the region.

The MS has become increasingly important in job creation in Latin America since the 1980s. One reason for this is associated with the declining importance of public sector jobs, in both relative and absolute terms. Another is the fall in employment by large private firms, as part of their strategy to reduce costs, to deal with more open borders. Although in the 1990s the latter's hiring ability recovered somewhat, they have not kept up with the overall pace of employment growth (Tokman, 2001).

Thomas (2001) states that in Latin America, globalization has increased the informality of the labour market in two directions: from the top down, due to the decline in social protection, the rise in temporary jobs and the decline in union coverage, and from the bottom up, as a result of growth without employment, which characterized the region in the past decade. This phenomenon revealed that national economies could post important figures in terms of output growth, without generating employment in the modern sector. As a result, a large proportion of the population that has joined the labour market has resorted to the informal economy, which has expanded in both absolute and relative terms.

The MS has not, however, been a mere receiver of labour expelled from larger companies. Studies on labour trajectories of microproducers tend to coincide on two types of findings: their original employment as wage-earners and the voluntary nature of their mobility, motivated by the search for independence and better income, combined with family reasons, in the case of women (Trejo, 2001; Valenzuela, Márquez and Venegas, 2001)

As part of the informal economy, they are very heterogeneous and are influenced by diverse factors that influence their size and composition, which, moreover, are rarely gender neutral. Thus, the MS is a more important source of employment for men than for women. In 2003 it accounted for $43.3 \%$ of male employment and just 34.6\% of female employment in Latin America. Moreover, the participation gap between men and women in the sector has widened. In the early 1990s, it was 5.3 percentage points, while ten years later it had risen to 9 percentage points (today it stands at 8.7 percentage points). These figures indicate that while women still face barriers to enter the MS, men's employment in this sector is rising more quickly.

\footnotetext{
${ }^{7}$ Nonetheless, the informality gap between men and women (six percentage points in 2003) has grown narrower, since men's situation has worsened more quickly than women's. In 1998, this gap was eight percentage points.
} 
Gender gaps also reveal that within the informal economy women are concentrated in lower quality jobs, as self-employed workers, while men dominate microbusiness, which provides better quality jobs.

On examining the structure of employment in Latin America by country, three types of country appear, depending on the weight and characteristics of their informal economies. These groupings reveal patterns that show the enormous heterogeneousness of the region, in terms of the size of the MS, the characteristics of its members, the sector's behaviour in different economic cycles, its internal composition (according to the prevalence of the most precarious sector, involving self-employment and survival activities, compared to the most developed sector, microbusinesses) and its links with other sectors within the economy.

The first type of country consists of those with an extensive, informal entrepreneurial culture, expressed as the large amount of employment within the informal economy, which in turn is extremely sensitive to economic cycles, tending to rise during belt-tightening episodes and fall when the economy is booming. In these cases, the adjustment to the labour market tends to occur not only through unemployment, but also through a decline in the quality of jobs, mainly through a rise in self-employment. Three of the countries studied belong in this group: Colombia, Ecuador and Peru.

The second type represents intermediate conditions in terms of the size of the MS, falling within the regional average or slightly below it. More economically advanced than the previous group, subsistence and more developed forms closer to modern companies coexist in informality. This group includes Argentina and Mexico.

The third type has a less extensive informal sector, well below the regional average. Within the MS, the percentage of microbusiness is higher than for the previous two groups, showing a development pole capable of generating higher quality jobs. Chile is of this type. 
Table 1: Main economic and labour indicators, selected countries

\begin{tabular}{|c|c|c|c|c|c|c|c|c|c|}
\hline Countries & \begin{tabular}{|c|} 
Average \\
GDP \\
growth \\
rate \\
$1990-$ \\
1999 \\
\end{tabular} & $\begin{array}{c}\text { Per } \\
\text { capita } \\
\text { income } \\
2000 \\
\text { (US\$) }\end{array}$ & \begin{tabular}{|c|} 
Gini \\
coefficient \\
1999
\end{tabular} & 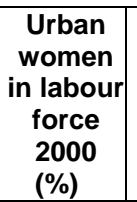 & $\begin{array}{l}\text { Urban } \\
\text { unemploy- } \\
\text { ment } \\
2002 \\
(\%)\end{array}$ & 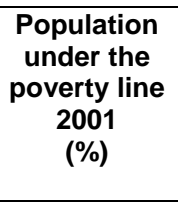 & \begin{tabular}{|c|} 
Employed in the \\
microbusiness \\
sector \\
2002 \\
$(\%)$
\end{tabular} & $\begin{array}{c}\text { Employed } \\
\text { in the } \\
\text { informal } \\
\text { economy } \\
\text { informal }^{\mathrm{d} /} \\
2002\end{array}$ & $\begin{array}{c}\text { Informal } \\
\text { economy } \\
\text { over GDP } \\
1999 / 2000^{b /} \\
(\%)\end{array}$ \\
\hline Argentina & 4.0 & 7104 & 0.542 & 46 & 21.5 & 30.3 & 39.2 & 5.2 & 25.4 \\
\hline Chile ${ }^{\mathrm{e} /}$ & 6.7 & 4705 & 0.559 & 42 & 9.0 & 20.0 & 32.2 & 5.9 & 19.8 \\
\hline Colombia $^{\mathrm{e}}$ & 2.7 & 2184 & 0.572 & 55 & 16.2 & 54.9 & 50.3 & 5.3 & 39.1 \\
\hline Ecuador ${ }^{\mathrm{c} / t /}$ & 1.7 & 1346 & 0.521 & 51 & --- & 60.2 & 50 & 5.1 & 34.4 \\
\hline Mexico & 3.5 & 4901 & 0.542 & 42 & 2.7 & 42.3 & 36.8 & 4.3 & 30.1 \\
\hline Peru & 4.0 & 2279 & 0.545 & 55 & 9.4 & 49.0 & 50.8 & 5.4 & 59.9 \\
\hline
\end{tabular}

Source: Author's calculations using data from the ILO and ECLAC.

Note: Indicators for Argentina changed drastically in 2002, as a result of the end to foreign exchange parity and the economic crisis. That year the population under the poverty line reached over $50 \%$ and per capita income, which had been almost US\$ 8,000 annually in 2000, fell to US\$ 2,750 in 2002.

a/ The Gini coefficient ranges from 0 to 1 . Values equal to 0 are interpreted as the absence of inequality, while the closer they are to 1 , the more inequality exists.

b/ Taken from Schneider (2000), who defines the informal economy as unreported earnings from the legal production of goods and services.

c/ Ecuador, urban poverty.

d/ Includes independent workers, owners and employers in microbusinesses with up to five employees and domestic service.

e/ The data in the columns "Microbusiness sector employees" and "informal sector employees" for these two countries are for 2000 .

f/ No information available for 2002 .

Poverty and informality are strongly related. Countries with the highest indices of poverty are also those with the largest informal economies, in which self-employment is particularly important. These activities, however, are unable to generate enough income, creating a vicious circle of poverty. Despite the strong link between income and poverty, there is no clear relationship between income, the structure of employment and the importance of the MS within employment. This seems paradoxical, given the decisive role that employment and the labour market play in income distribution. Latin America is well known as the region with the most unequal income distribution in the world and this was confirmed in the 1990s, when, despite the fact that most economies performed better than in the 1980s, conditions did not significantly improve and in some countries they even worsened (ECLAC, 2004). The most plausible explanation, aside from problems with the respective bases and comparisons, could lie in a combination of factors determining income distribution, particularly the concentration of property and assets, women's participation in the labour force, and the educational system's coverage. 


\subsection{Countries with high microbusiness employment, especially self-employed workers}

The first group of countries consists of the three chosen by the Andean region for this study: Colombia, Ecuador and Peru. In all three the percentage of the labour force employed in the MS is very high and the informal economy's contribution to Gross Domestic Product (GDP) is significant, revealing how consolidated this kind of activity has become. With a high poverty rate and low per capita income, MS activities mainly involve survival and family type activities. They create very precarious forms of employment, have few links with more formal economic processes, and their capacity for accumulating capital is low or non-existent. They operate in popular (low-income) sectors, with little capital, minimal technology and low productivity. Their market consists mainly of other residents of the same neighbourhood, with little consumption power, since they are equally poor. When linked to larger firms, this occurs primarily through home work, ${ }^{8}$ for which they receive little income and have little ability to negotiate (Tomei, 1999).

For an important percentage of the employed in these three countries, their entry into a microbusiness reflects traditional paradigms, in which the weight of this sector directly reflects modern firms' inability to create enough jobs and respond to the demand for work. The modern sector of the economy is insufficiently developed in Ecuador and Peru, ${ }^{9}$ and no significant improvement has become apparent in recent years with the opening up of new markets and adjustment programmes. In Colombia, the modern sector underwent a serious crisis in the 1990s, as a result of the sudden opening of the economy, which eroded its ability to absorb employment, pushing it down from $44.7 \%$ in 1990 to $30.9 \%$ in 2003 (ILO, 2004)

The average rate of women's participation in the labour force in these countries is higher than the regional average, particularly the proportion of women from the lowest income households. Large contingents of poor women have joined the MS, mainly as selfemployed workers in survival activities, to contribute to maintaining their households. As their income is very low and the conditions in which their businesses operate very precarious, they operate on a much reduced scale, with no ability to accumulate capital.

In these countries, the MS seems to be the only work option for a large contingent of poor men and women, especially those with less education, many of whom do not even make enough to escape from poverty.

\footnotetext{
${ }^{8}$ The ILO's Convention No. 177 defines home work as that carried out in a worker's home or in other premises of his or her choice, other than the workplace of the employer, for which the worker receives remuneration (i.e. does not sell the product directly in the market place) and where the employer provides the specifications for producing the produce or service, irrespective of who provides the necessary materials, inputs and equipment.

${ }^{9}$ Today, small, medium and large private firms generate around one-quarter of employment in Ecuador and a little more than one-third in Peru.
} 
The second type of country is represented by Argentina ${ }^{10}$ and Mexico. In both, the MS accounts for a less important share of national employment, its contribution to GDP is lower, and poverty levels are lower than the first country type.

Argentina and Mexico are among the region's largest countries in terms of both their population and their economies. They have local markets of considerable size and a well developed manufacturing sector. Their microbusiness is mixed and reflects the heterogeneous nature of their economic structures. One group mainly involves microbusinesses (units with more than one worker) and to a lesser degree self-employed individuals, who relate directly or indirectly to industrial work or services offered in more formal spheres within the modern sector of the economy. An entrepreneurial approach to accumulation prevails among them and the sector's links are established through different contractual arrangements, including subcontracting services or through links to productive processes for large firms. To the best of their ability they comply with a large percentage of regulations and the country's legal framework, and at the same time benefit from them. In Mexico in particular, the industrial sector was strengthened by incorporating technologies and a strong rise in manufactured exports, which favoured the more modern area and consolidated the MS, a situation associated with the free trade agreement with the United States and Canada (Stallings and Peres, 2000). In Argentina, it has been the tertiary sector, particularly with regard to financial and other services associated with companies, that contributed directly to the progress of the most developed segment of microbusinesses.

Another part of the MS essentially consists of the self-employed and family microbusinesses, which are more survival-oriented, with minimal access to productive resources and few possibilities of achieving some form of economic accumulation. They function within an economy submerged in informality and generally do not have the permits necessary to set up and operate. Nor do they pay the corresponding taxes. These are workers with little education and few skills, or educational credentials insufficient to give them access to jobs in the more modern, stronger performing sectors, or they have been expelled from these.

In both countries, the MS includes both poor sectors with few labour options and non-poor entrepreneurs who opt for working independently. The relatively scarce presence of women in this sector in Mexico is one of the reasons behind women's low participation in the labour force. ${ }^{11}$

\subsection{Countries with a small but more developed microbusiness sector}

Chile represents the third and last type of country. There, the behaviour and characteristics of the MS are very different from the patterns most common to the region. The informal economy's importance to the GDP and employment is the lowest of all the countries

10 Although in Argentina's case there were significant changes in several indicators after the economic and political crisis unleashed in December 2001, which caused a sharp rise in unemployment and poverty rates, the MS does not appear to have changed significantly (Cortés, 2003).

${ }^{11}$ This data is for urban areas. National figures may change, since trends apparent at the rural level were different. 
analyzed. Historically speaking, it has not been a sector of refuge, as the procyclic behaviour of employment in the MS reveals ${ }^{12}$ (Valenzuela and Venegas, 2001). With a poverty rate well below the regional average, the importance of this sector to national employment is much lower than the other countries studied. The composition of the MS is also different and consists mainly of multipersonal businesses. Self-employed work accounts for less than half the jobs in the sector, the lowest figure for any of the countries analyzed.

Microbusiness activity enjoys a relatively high level of formality, functioning within an economic rather than a survival-oriented context, and has a capacity for accumulation that, while relatively low, does allow it to project itself over time.

Chile's economic performance in the 1990s, despite the small size of its own market, was the motor driving the development of the MS. This was the only country in the region where investment and productivity of all sectors rose steadily. Notwithstanding, poor income distribution - among the worst in Latin America - remained unchanged.

\subsection{Women under-represented in the microbusiness sector}

The contribution of MS to employment is significant in Latin America: it accounts for more than $40 \%$ of jobs. In 2003, this sector accounted for more than $50 \%$ of non-farming jobs in Peru and Colombia and $46 \%$ in Ecuador. In these three countries it is well above the average for this sector in Latin America and is the main source of employment at the national level. In Argentina it approaches the regional average, while in Mexico it accounts for $36 \%$ of employment in urban areas. Only in Chile does it account for less than onethird of those employed.

The impact of MS on total jobs for women in Latin America is less than for men. This indicates that in the region women are underrepresented in the microbusiness sector. There is a gender gap between men and women: while $34.6 \%$ of women's jobs are in the MS, $43.3 \%$ of men's are in this sector. Moreover, this gap increased during the 1990s, since the importance of women in this sector did not change much (one percentage point between 1990 and 2003), while in the case of men it rose rather significantly, by 4.5 percentage points during the same period. This phenomenon reflected adjustment processes and the reorganization of production occurring in modern, private firms, in branches that primarily employed men. This led to the microbusiness sector becoming a refuge for many workers, particularly those with less education (Weller, 2000).

Of the six countries considered in this analysis, Peru is the only one where the percentage of women employed in the MS is higher than that of men. The other five remain within the regional average, confirming that this sector is not very developed for women.

\footnotetext{
12 This tendency, however, was broken by the economic crunch experienced in the early 2000s, at which point it behaved in a countercyclical fashion.
} 
Figure 1 : Percentage of the non-farming workforce employed in the microbusiness sector, by sex, 2003

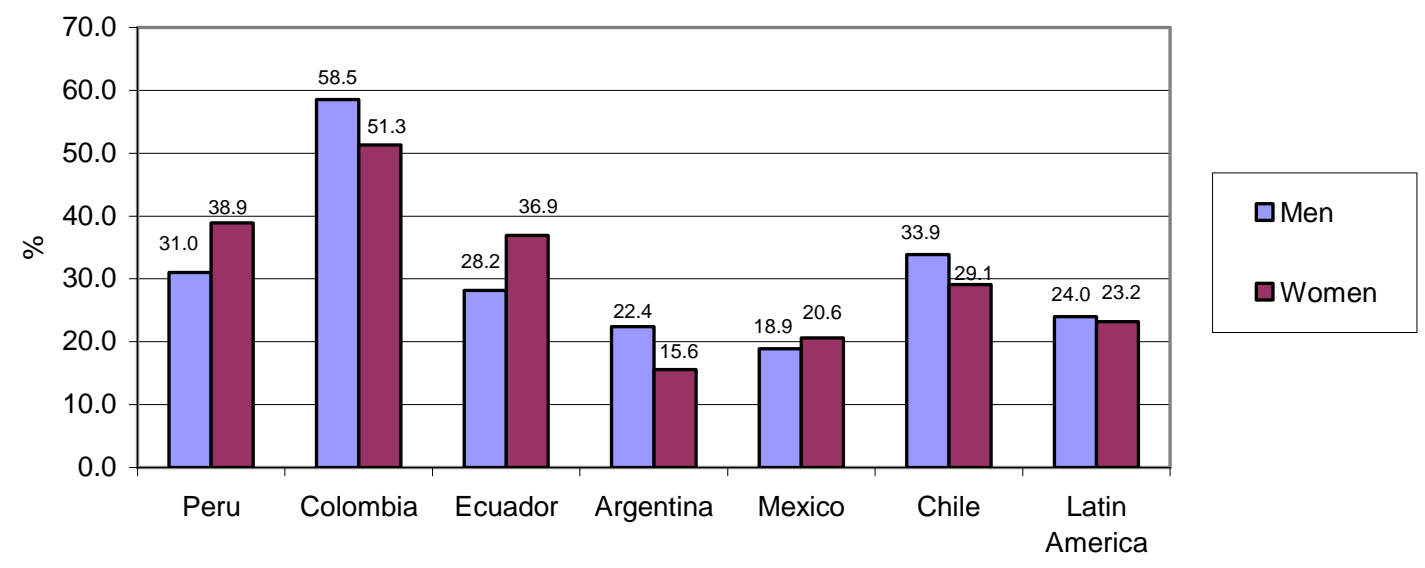

2003

Source: Author's calculations using data from the ILO.

Although women are underrepresented in the MS, it remains a very important source of employment for them, especially in Peru, Colombia and Ecuador, as Figure 1 reveals.

Although men's integration in higher technology jobs was stronger, employment in the MS grew for both men and women in the 1990s in absolute terms in every one of the region's countries. In relative terms, the sector's importance to regional employment rose by 3.9 percentage point between 1990 and 2003, or an increase of almost 16 million people. The MS was responsible for generating most new jobs in Latin America, especially for men. For every ten people joining the labour market during the decade, six did so in this sector. In the case of men this figure was higher, with the MS accounting for $70 \%$ of new jobs. ${ }^{13}$

Thus, in all countries examined in this study except Peru, by 2000 men accounted for a larger percentage of those employed in the MS in 2000 than in 1990, because more men than women had entered the sector. The largest gaps by gender, led by men, were to be found in Argentina (10 percentage points), Ecuador (9.6 percentage points), Colombia (8.7 percentage points), Mexico (7.3 percentage points), with the least difference in Chile (5.8 percentage points). Only in Peru did the gap favour women (2.5 percentage points).

Of the countries studied, Colombia and Peru experienced the most growth in the MS between 1990 and 2000, at the expense of a significant decline in private sector employment in Colombia and a less severe decline in Peru, where, moreover, public service employment also plunged. In Argentina and Ecuador, in contrast, the MS' importance to employment declined slightly and private employment in larger firms rose. Mexico and Chile experienced minor changes.

\footnotetext{
${ }^{13}$ Although this study does not analyse conditions affecting domestic service, the significant growth experienced by this segment cannot be forgotten. In 2003 it accounted for $15.5 \%$ of women's employment in the region, that is 1.7 percentage points more than in 1990. In this period, around $20 \%$ of new jobs were in domestic service. This figure was significantly influenced by the strong rise in domestic service in Colombia and Brazil, and to a lesser degree in Argentina. In most of the region's countries, this segment grew about $10 \%$.
} 


\subsubsection{Women concentrated in the most precarious MS sectors: self-employed and non- remunerated family members}

The MS consists of two large groups: those working in single person microbusinesses and those working for microbusinesses with several employees. In the case of the former, these are independent workers active in different forms of self-employment, with few qualifications and little capital, involved in low productivity businesses, generally at a survival level. ${ }^{14}$ They perform tasks requiring few skills in precarious conditions, on a small scale in the street, in small businesses in their own homes, or as workers in other people's homes.

The second group, microbusinesses employing more than one person, are businesses with a capital base that allows them to develop a larger scale operation and, often, employ personnel. They operate on a more solid economic base, although often these are family businesses.

In Latin America, the first segment is significantly more important than the second in terms of the number of people employed. In 2003, almost $60 \%$ of people working in the MS, one-quarter of all those employed in the region's urban areas, were self-employed or non-remunerated family members. Microbusinesses employing several people (including employers and wage-earners), meanwhile, accounted for $16 \%$ of regional employment on average.

\footnotetext{
${ }^{14}$ By definition, professionals and technicians have been excluded.
} 
Table 2: Distribution of microbusiness jobs by occupational category and sex, 2000 (non-farming jobs)

\begin{tabular}{|c|c|c|c|c|c|c|}
\hline Country & Sex & $\begin{array}{c}\text { Employers } \\
(\%)\end{array}$ & $\begin{array}{c}\text { Self-employed } \\
\text { worker } \\
(\%)\end{array}$ & $\begin{array}{c}\text { Wage-earners } \\
(\%)\end{array}$ & $\begin{array}{c}\text { Non-remunerated } \\
\text { family member } \\
(\%)\end{array}$ & $\begin{array}{c}\text { Total } \\
(\%)\end{array}$ \\
\hline \multirow{2}{*}{ Argentina } & Men & 9.0 & 49.6 & 40.2 & 1.2 & 100.0 \\
\hline & Women & 6.4 & 50.6 & 38.2 & 4.8 & 100.0 \\
\hline \multirow{2}{*}{ Chile } & Men & 9.8 & 29.6 & 58.6 & 2.0 & 100.0 \\
\hline & Women & 6.4 & 33.8 & 51.7 & 8.1 & 100.0 \\
\hline \multirow{2}{*}{ Colombia } & Men & 10.8 & 58.6 & 29.1 & 1.5 & 100.0 \\
\hline & Women & 6.1 & 64.1 & 24.2 & 5.6 & 100.0 \\
\hline \multirow{2}{*}{ Ecuador } & Men & 8.5 & 48.6 & 34.4 & 8.5 & 100.0 \\
\hline & Women & 4.4 & 60.4 & 15.5 & 19.7 & 100.0 \\
\hline \multirow{2}{*}{ Mexico } & Men & 12.6 & 41.4 & 41.2 & 4.8 & 100.0 \\
\hline & Women & 4.9 & 41.4 & 30.4 & 23.3 & 100.0 \\
\hline \multirow{2}{*}{ Peru } & Men & 13.0 & 47.7 & 32.3 & 7.0 & 100.0 \\
\hline & Women & 4.6 & 63.7 & 18.3 & 13.4 & 100.0 \\
\hline
\end{tabular}

Source: Special calculations, ILO. Figures in bold represent categories where the percentage of women is greater than the percentage of men.

Upon analyzing the internal composition of the MS, we can see that more women than men are concentrated in the self-employed category. In Colombia, Ecuador and Peru, independent work accounts for more than $60 \%$ of the female labour force employed in microbusiness. In Argentina, they account for half of those employed in this sector, and in Mexico 40\%. Only in Chile, where they account for one-third of the total, is their share low. The importance of this category to women's employment partly reflects the greater freedom it offers in terms of organizing work, making it easier to reconcile family and working responsibilities. Moreover, a business that depends solely on one's own labour requires less capital, knowledge and access to networks than one that hires employees. This makes it more accessible to women, who face additional restrictions in creating new businesses, because they have fewer resources of their own and bear the weight of gender socialization that still emphasizes their primary role as mothers and wives, stereotypes and prejudices about their ability to participate successfully in the business world.

From 1990 to 2003, the importance of self-employed work to male employment rose (2.4 percentage points), while it remained constant within women's employment (23.2\%). In Colombia this category shot upward (16 percentage points in the case of men and 12.4 for women), leading growth in the region. The decline in the Colombian economy from the end of the previous decade ${ }^{15}$ and plunging employment in the private sector, ${ }^{16}$ combined

\footnotetext{
${ }^{15}$ Per capita GDP performed poorly from 1996 on. That year it stagnated, the next it rose just $1.4 \%$, before falling $1.1 \%$ in 1998 and $5.6 \%$ in 1999.

${ }^{16}$ Employment in small, medium and large private firms fell 7.4 percentage points between 1990 and 2000 .
} 
with political violence and the displacement of refugees were some of the factors that led to this substantial rise in self-employment. In Peru, employment in this category fluctuated, peaking in 2000 .

Figure 2: Percentage of the non-farming workforce, self-employed, by sex, 2003

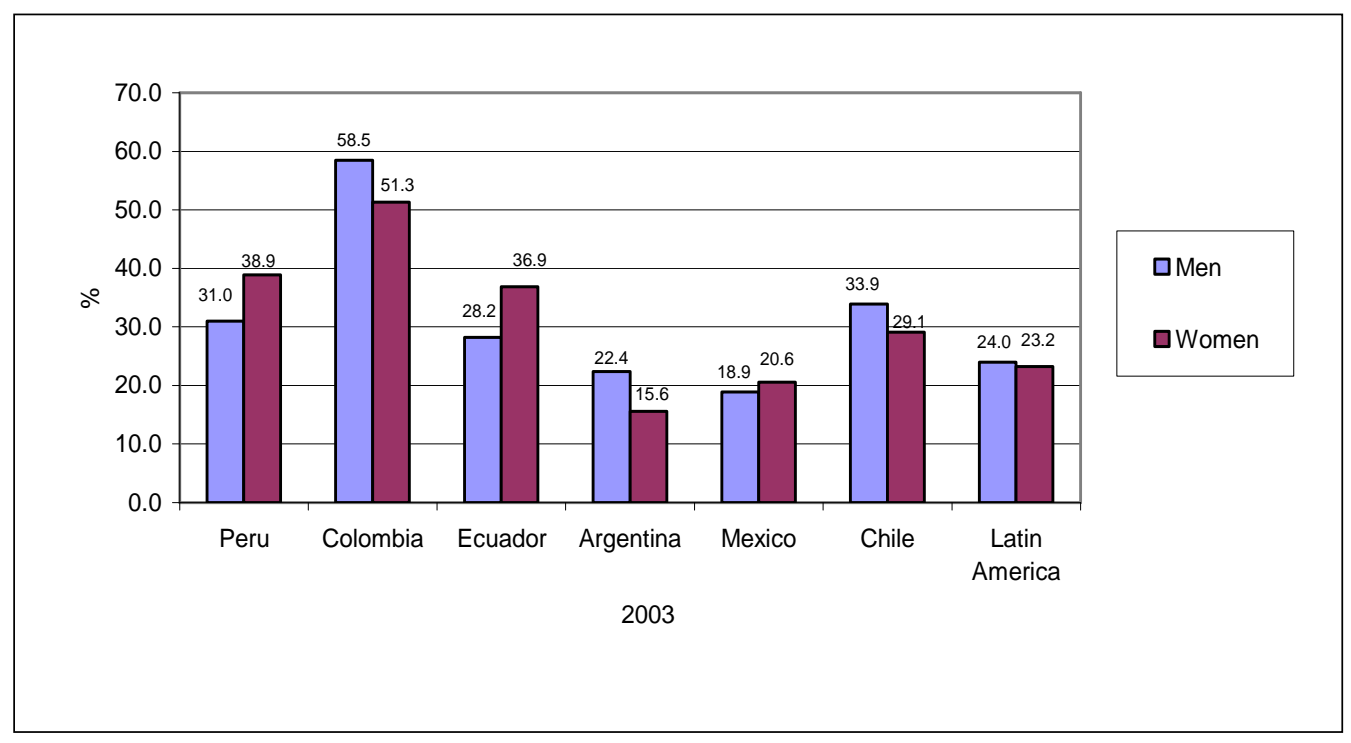

Source: Author's calculations using data from the ILO.

Another category with a strong women's presence is that of work by non-remunerated family members (NFM). Women account for $60 \%$ to $70 \%$ of all NFM. The incidence of unremunerated family members' work in these countries is very high among women, and although lower, is also significant among men. In Mexico, NFM accounts for almost onequarter of women's employment in this sector and in Ecuador one fifth. In these countries (as well as in Chile) the percentage of women among NFM is higher than the percentage of women employers in the MS (Table 2).

NFM is the most precarious form of participation in the labour force and reveals the vulnerable nature of most microbusinesses. This category is clearly dominated by women in every country, involving an auxiliary function in managing a business, no personal income, nor a basis for developing business ability or economy autonomy. This category both expresses and tends to reinforce gender inequalities.

The weight of these workers declined in the 1990s in all countries except Peru (men and women) and Ecuador (only men). Nonetheless, the importance of this category to women's employment in Mexico and Ecuador remained very high in the early 2000s.

\subsubsection{Male predominance in microbusinesses}

In Latin America, microbusiness units with more than one employee are rather less important than self-employment in terms of the number of jobs they create.

Microbusinesses' share of national employment rose in every country analysed, except Colombia. In this case, there seems to have been a displacement to the self-employed category (that is, microbusinesses that laid off workers, who in turn became selfemployed), which would also help to explain the latter's explosive growth. The decline in microbusiness employment in Colombia affected women in particular, revealing their greater vulnerability to the adverse economic and political conditions that the country 
experienced in the past decade. In Mexico and Peru this sector's importance to national employment rose the most. In both cases, male employment performed more strongly than women's, especially in Peru, where the rise in male employment in microbusinesses was double that of women's.

Microbusiness is a more important source of employment for men than for women. Men's larger presence in microbusiness reflects their higher proportion in the two categories that compose it: owners and wage-earners.

In 2003, on average this sector accounted for $19.3 \%$ of total men's employment, but barely $11.4 \%$ of women's, in this region. In Argentina, Colombia, Ecuador and Peru, microbusiness' importance to employment was higher than the regional average, especially in the case of men. Gender gaps are very pronounced in five of the six countries analyzed. In Chile, the sector's importance is significantly less than the regional average and this is the only case where women have a relatively high participation in this sector, with the gender gap being smaller than the regional average (Figure 3). This situation is associated with the less precarious conditions in which women participate in the MS and their greater presence in microbusinesses employing several people.

Figure 3: Percentage of the non-farming workforce employed in microbusinesses, 2003

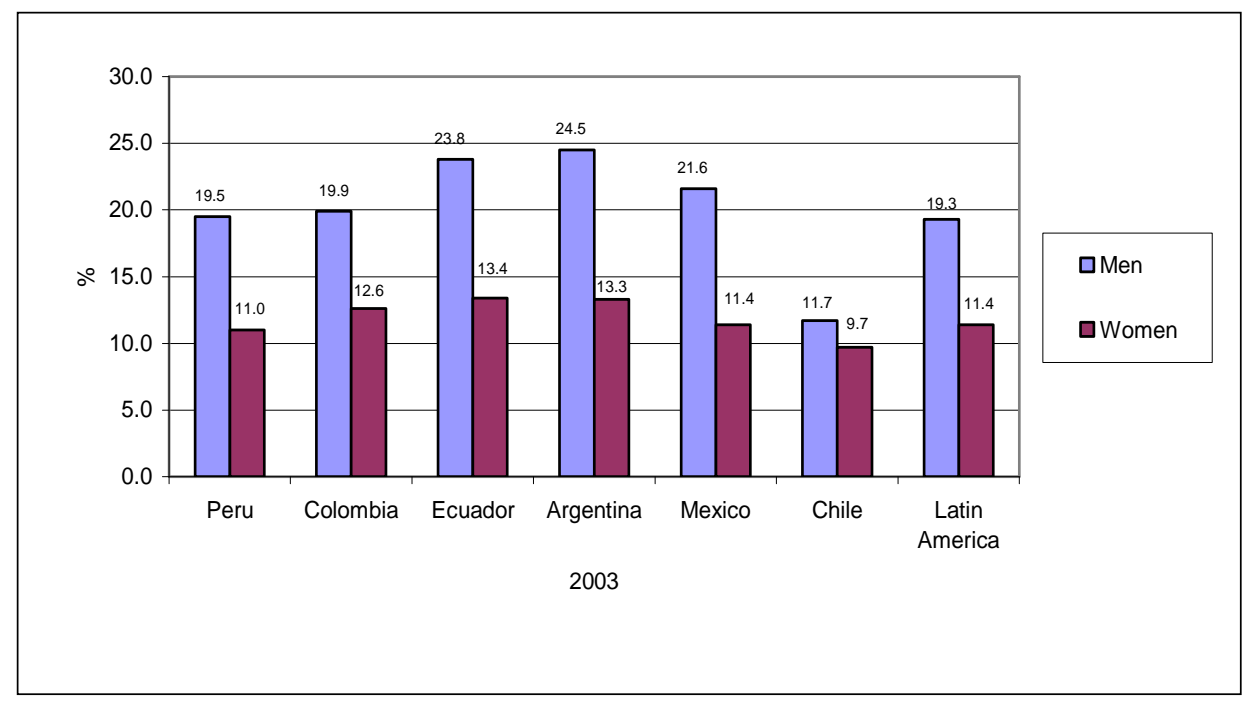

Source: Author's calculations using data from the ILO.

Female employers account for a minimal fraction of all women in the MS. In Argentina, Colombia and Chile their share reaches just over $6 \%$, while in other countries it is even lower. Male employers, in contrast, are numerous, more than $10 \%$ in Colombia, Mexico and Peru (Table 2).

Male dominance in the business world is stronger in larger firms, but is also apparent in microbusinesses. In every country studied, most microbusiness owners are men. The largest gender gaps are apparent in Peru and Mexico. In 2000, Peruvian women accounted for less than half of independent workers and barely one-fifth of all microbusiness employers, thus confirming gender disadvantages when it comes to larger scale businesses. Mexican women seem to face even greater hardships: barely $15 \%$ of microbusiness employers are women. In the remaining countries, the percentage of female owners is higher (over 25\%), but nowhere does it reach $30 \%$. 
Although women still face barriers for creating microbusinesses, they are advancing quickly in this field. In the 1990s, the number and percentage of women owning a microbusiness rose, even in Colombia, where the number of microbusiness owners overall fell. The growth rate for female microbusiness owners was higher than for their male peers and in most countries they went from accounting for just more than one-fifth to onequarter of this segment. The two countries with the largest percentage of female microbusiness owners behaved unevenly. Mexico saw a significant rise in the number of microbusinesses created, owned by both men and women, and the gap closed slightly. In Peru, in contrast, very few microbusinesses were created, half of them by women. Because of this, the gender gap in the microbusiness owner segment fell during this period. ${ }^{17}$

The wage-earners category is numerically more important than employers, but its importance within total employment depends on the microbusiness structure. Wageearners are especially significant in Chile, where they account for more than half those employed in the microbusiness sector. In Argentina and Mexico, which have consolidated microbusiness sectors, this is also a numerically important group, although less so than the self-employed. In contrast, in those countries, such as Colombia, Ecuador and Peru, where the MS is dominated by an extensive area of self-employment and informality, the percentage of microbusiness wage-earners is low, and its importance is even lower among women. Gender gaps are especially important in Ecuador, Mexico and Peru, where women tend to concentrate in the categories of self-employed or non-remunerated family members (Table 2).

Wage-earners' importance to MS employment rose significantly in the 1990s in both Argentina and Chile. In Argentina, this essentially reflected a rise in the size of microbusinesses (which received workers without this necessarily involving a rise in production or sales), while in Chile, it also reflected the creation of new microbusinesses. Chile was the only country in which in the past decade a significant number of women became wage-earners in microbusinesses, producing an important rise in their presence in this category (from 27\% of those employed in the MS in 1990 to 39.4\% in 2000). In Mexico, Peru and Ecuador the importance of wage-earners also rose, but only in terms of male employment. One possible explanation is that in those countries, microbusinesses in sectors that tend to prefer male labour (transportation, construction and some branches of industry) experienced growth and hired more labour.

\subsection{Women concentrate in a few sectors of activity}

More than half of non-farm female employment in the region is concentrated in the community, social and personal service sector and almost one-third in the wholesale and retail trade. If women in the financial, transportation and communications sectors are included, the importance of the tertiary sector to women's employment can be seen, as it accounted for $85.1 \%$ in 2003 . This sector also accounted for most of men's employment, although a much smaller proportion $(67.8 \%$, ILO, 2004).

During the 1990s, new jobs were generated mainly in tertiary activities, contributing to the incorporation of a large number of women into the labour force. Yet again this process reflected the growing polarization of Latin American society: the percentage of women wage-earners with an advanced education rose at the same time as a significant number of women with little education joined typically informal activities (Weller, 2000). Despite the length of time in the educational system in the countries studied, a substantial share of the work force still has little education, particularly in the first group of countries (Peru, Colombia and Ecuador), where from $12 \%$ to $29 \%$ of the labour force had less than five

\footnotetext{
${ }^{17}$ In $1990,15.1 \%$ of microbusiness owners in Peru were women. This rose to $21.4 \%$ in 2000.
} 
years of education. In any case, the educational credentials of both men and women employed in the MS are lower than the average for the labour force and the percentage of workers with this low level of education is also larger. In Colombia, 33\% of women in this sector have five years or less of education, while $26 \%$ are in this situation in Peru, $20 \%$ in Ecuador. This helps to explain both the strong concentration in self-employed work and their low income.

Within tertiary activities, some, such as wholesale and retail and personal services have seen their function as a refuge for people expelled from or unable to obtain work in more formal activities accentuated, due to lack of education, among other reasons. Because of this, women's and men's employment in the MS is even more concentrated than in the rest of the economy, reaching levels above the regional average.

The wholesale and retail trade dominates microbusiness activity, especially among women, while community, social and personal services are less important for women, compared to figures for larger companies. At the same time, occupational segregation by sex is more apparent in the MS than in the rest of the economy, through a drastic separation between male and female trades and women's greater concentration in a small number of sectors, particularly wholesale and retail.

Gender segregation in the labour force is very widespread, with profound roots in the sexual division of labour, and is apparent in the segmentation of the labour market into separate parts in which the remuneration and working conditions are different and mobility is limited. The extensive literature on this subject has shown that despite women's massive incorporation into the work force, women are still concentrated into a small number of jobs, defined as traditionally for women, and into lower ranking positions within each occupation. This produces a polarization of the labour market by gender and, along with other factors, is responsible for the differences in income between men and women (Anker, 1998; Jacobsen, 1998).

For women, microbusiness activity centres mainly on commerce. With the exception of Argentina, this is the most important branch for women employed in the MS. In Peru, it accounts for three-quarters of women's employment, in Ecuador and Chile almost $60 \%$, and in Mexico and Colombia almost half. Services also see a large concentrate of women's employment in this sector in Argentina (51.8\%) and Mexico (38.8\%), while manufacturing is significant in Colombia (19.1\%) and Ecuador (19\%, Table 3).

Women's choice of the area in which to develop their business seems to be very influenced by gender stereotypes and the type of socialization received, which serves as the apprenticeship they take with them into any economic activity. The high concentration of women in very small-scale commerce, usually linked to the food sector, is an example of this. The knowledge acquired in the preparation of food within the household makes it possible to manage more flexibly the place and time for remunerated work, in response to limitations on mobility and scheduling, which arise from the need to reconcile productive tasks with family and domestic responsibilities.

A large majority of women in commercial activities work directly out of their homes, thereby making better use of their time since they don't have to commute to work, reducing their rent, improving their flexibility, control and ability to organize their daily work agenda, as well as making it easier to combine work with domestic tasks and child care. In this group, a large percentage is involved in food commerce. In the case of selling non-perishable foods, a few minor transformations to the home are enough to make it possible to sell to the public. The sale of perishable foods requires more investment to meet the requirements for a sanitary permit, but often this is simply omitted, especially by those who sell in the street. 
Women's "preference" for commerce may also be influenced by the limitations on their entry into other sectors and the reduced demands in terms of starting capital and infrastructure, required by this area. The disadvantage of a choice like this one is that it generates very small scale business, such as that practiced by street sellers or in the home itself, where women often operate with help from their children, at a survival level, selling to others as poor as they are, within the same neighbourhood.

For men employed in the MS, commerce is also the main activity, accounting for $44 \%$ of employment in Ecuador and 29.6\% in Argentina. Next in importance is services (except in Peru and Ecuador, where this area is not very important for men), with the rest of employment distributed among industrial activities, construction and transportation (Table $3)$.

Table 3: Distribution of total non-farming employment in the microbusiness sector by branch of activity and sex, 2000 (percentage)

\begin{tabular}{|l|c|c|c|c|c|c|c|c|c|}
\hline Country & Sex & $\begin{array}{c}\text { Manufac- } \\
\text { turing }\end{array}$ & $\begin{array}{c}\text { Electricity, } \\
\text { gas and } \\
\text { water }\end{array}$ & Construction & $\begin{array}{c}\text { Wholesale } \\
\text { and retail, } \\
\text { restaurants } \\
\text { and hotels }\end{array}$ & $\begin{array}{c}\text { Transpor- } \\
\text { tation } \\
\text { and } \\
\text { communic. }\end{array}$ & $\begin{array}{c}\text { Financial } \\
\text { establishments }\end{array}$ & Services & Total \\
\hline \multirow{2}{*}{ Argentina } & $\mathrm{M}$ & 13.4 & 0.1 & 21.5 & 29.6 & 11.8 & 4.2 & 19.5 & 100.0 \\
& $\mathrm{~W}$ & 8.6 & 0.0 & 0.3 & $\mathbf{3 2 . 0}$ & 1.9 & $\mathbf{5 . 4}$ & $\mathbf{5 1 . 8}$ & 100.0 \\
\hline \multirow{2}{*}{ Chile } & $\mathrm{M}$ & 13.4 & 0.3 & 18.0 & 32.0 & 16.2 & 3.0 & 17.2 & 100.0 \\
& $\mathrm{~W}$ & $\mathbf{1 6 . 0}$ & 0.0 & 0.3 & $\mathbf{5 7 . 3}$ & 2.2 & $\mathbf{3 . 4}$ & $\mathbf{2 0 . 8}$ & 100.0 \\
\hline \multirow{2}{*}{ Colombia } & $\mathrm{M}$ & 14.2 & 0.4 & 11.1 & 35.2 & 14.0 & 4.5 & 20.5 & 100.0 \\
& $\mathrm{~W}$ & $\mathbf{1 9 . 1}$ & 0.0 & 0.4 & $\mathbf{4 6 . 6}$ & 1.6 & 3.6 & $\mathbf{2 8 . 8}$ & 100.0 \\
\hline \multirow{2}{*}{ Ecuador } & $\mathrm{M}$ & 19.4 & 0.1 & 13.0 & 44.4 & 14.8 & 3.2 & 5.1 & 100.0 \\
& $\mathrm{~W}$ & 19.0 & 0.0 & 0.7 & $\mathbf{6 1 . 6}$ & 0.9 & 2.6 & $\mathbf{1 5 . 3}$ & 100.0 \\
\hline \multirow{2}{*}{ Mexico } & $\mathrm{M}$ & 12.5 & 0.1 & 13.8 & 32.3 & 12.9 & 0.5 & 27.9 & 100.0 \\
& $\mathrm{~W}$ & 10.4 & 0.0 & 0.1 & $\mathbf{5 0 . 3}$ & 0.5 & 0.5 & $\mathbf{3 8 . 1}$ & 100.0 \\
\hline \multirow{2}{*}{ Peru } & $\mathrm{M}$ & 14.4 & 0.1 & 12.3 & 39.5 & 25.6 & 2.6 & 5.5 & 100.0 \\
& $\mathrm{~W}$ & 8.3 & 0.0 & 0.0 & $\mathbf{7 6 . 5}$ & 1.3 & 2.4 & $\mathbf{1 1 . 5}$ & 100.0 \\
\hline
\end{tabular}

Source: Author's calculations using data from the ILO.

Note: Branches where the percentage of women is larger than men are noted in bold.

Manufacturing concentrates a relatively low percentage of those occupied, for both sexes, although its importance varies by country. Where people participate in the whole cycle of production and commercialization it is possible that there is an over-registration in the field of commerce and the proportion of those employed in manufacturing may actually be higher. Manufacturing activities carried out by men and women are different. In the case of women, textiles and clothing is the main manufacturing field, which has been threatened by low-cost imports from Asia.

Services are also strongly segregated by sex. Men have a strong presence in repair services traditionally considered a male preserve (electrical appliances, furniture, cars, plumbing and electricity) and some personal services (gardening, loading, etc.). Women, in contrast, work mainly as hairdressers, sales people and in other similar activities. 


\section{Enormous income inequalities by sex in the microbusiness sector}

Early in the 2000s, the difference in income between men and women employed in Latin America remains very marked. ${ }^{18}$ Women receive less income than men in every segment of the labour market. On average, women's monthly income stood at $66 \%$ of men's in 2000 (ILO, 2001). The income gap between men and women has tended to decline, since in 1990 women received just $59 \%$ of men's income.

Segmentation of the labour market by sex seems to be one of the main factors behind women's lower income, since they have greater access to the worst paying sectors of the market. Some authors conjecture that this could be due to the fact that here they apply skills learned as part of their gender role and therefore receive no retribution for their specialization (Gálvez, 2002). The unequal composition of each labour segment by sex is, therefore, a decisive factor in the income gap by sex. For example, in independent activity women account for a small share of the owners, who earn the most, and a large percentage of those working alone. Moreover, when they do work as owners, women tend to be involved in smaller scale operations with less growth potential than the businesses run by men.

Although in every occupational segment there is significant inequality between men's and women's income, the size of gaps varies significantly between each one. In Latin America, the average monthly income of women employed in microbusinesses had reached $71 \%$ of men's in this type of establishment, by the end of the 1990s, while in the case of those working on their own, women received less than half the income of men (49.2\%, ILO, 2001). This income disparity between men and women employed in microbusiness is less than for those who are self-employed, mainly because of the importance of the wageearner segment, a category that exhibits more equality of income both within the MS and beyond it.

The income of women owning microbusinesses (employers) in Chile and Argentina is particularly high compared to other countries. Nonetheless, men's income doubles that of women in this same category. At the other extreme, the income of self-employed women in Colombia, Ecuador and Peru is very low, confirming the precarious nature of their participation in the work force. The low income of self-employed women in Mexico is also noteworthy, as it points to their location at the subsistence end of the spectrum, reaffirming the wide range of conditions within that country's MS, where male owners of microbusinesses earn 10 times the income that female owners do (Table 4).

${ }^{18}$ This section refers to non-farming remunerated workers and does not include unremunerated family members. 
Table 4: Average monthly income of those employed in the microbusiness sector, by sex, 1999 (in multiples of the respective poverty line)

\begin{tabular}{|l|c|c|c|c|c|}
\hline \multicolumn{1}{|c|}{ Countries/years } & Sex & Employers & $\begin{array}{c}\text { Wage- } \\
\text { earners }\end{array}$ & $\begin{array}{c}\text { Self-employed } \\
\text { workers }\end{array}$ & $\begin{array}{c}\text { Total } \\
\text { employed }\end{array}$ \\
\hline $\begin{array}{l}\text { Argentina } \\
\text { (Greater Buenos }\end{array}$ & Men & 21.7 & 4.0 & 7.1 & 7.4 \\
Aires) & & & & \\
& Women & 12.6 & 3.2 & 4.3 & 4.8 \\
\hline Chile (2000) & Men & 24.5 & 3.7 & 5.8 & 8.5 \\
& Women & 14.0 & 3.3 & 3.9 & 5.2 \\
\hline Colombia & Men & -- & -- & 2.4 & 3.8 \\
& Women & -- & -- & 1.3 & 2.8 \\
\hline Ecuador & Men & 6.4 & 1.8 & 2.3 & 3.4 \\
& Women & 4.7 & 1.6 & 1.2 & 2.1 \\
Mexico (2000) & Men & 13.5 & 2.4 & 4.7 & 5.2 \\
& Women & 9.7 & 1.7 & 1.4 & 2.8 \\
\hline Peru & Men & 4.9 & 2.3 & 2.1 & 3.9 \\
& Women & 3.2 & 2.0 & 1.2 & 2.4 \\
\hline
\end{tabular}

Source: Author's calculations, using data from ECLAC.

In every category of the MS, women receive less income than men, whether calculated by monthly income or hours worked. In this last case, gaps decline slightly, but do not disappear.

Women's lower income compared to men's appears even when their educational level is similar or better than their male peers, except in Peru. The literature suggests that women's income in microbusinesses does not show the same pattern of yields for education and experience as men's, mainly because of the areas in which they are primarily employed (Valenzuela and Venegas, 2001). Moreover, although in many countries self-employed female employers and workers have more education than men, their education is less relevant to their business activity than men's (Stanger et al., 2002).

Among employers, the gap for monthly income by sex is very high in Chile and Argentina, the only countries where this category obtains income significantly higher than the national average. In Ecuador, in contrast, this gap is significantly smaller and, as in Mexico and Peru, is below the average gap for the total of those employed in the respective countries.

The trend in income inequality between men and women microbusiness owners during the 1990s varied, falling in Chile and Mexico and rising in Argentina, Ecuador and Peru (Table 5).

The positive trend in the income gap in Chile and Mexico reflected different causes. In Chile, income levels generally rose, and rose more for women. In Mexico, in contrast, women's real income remained almost constant (rising very slightly), while men's fell.

The decline in women's conditions in Argentina reflected a slight decline in their real income, while men's recovered slightly. In Ecuador, real income rose for workers of both sexes, but men's rose much more significantly. Data from Peru reflect only the end of the decade and show a negative tendency for both men and women, worse in the case of the latter. 
Table 5: Female employers' percentage of average monthly income compared to male employers in the microbusiness sector

\begin{tabular}{|c|c|c|c|}
\hline Countries & 1990 & 1999 & $\begin{array}{c}\text { Change in the gap, } \\
1990-1999 \\
\text { (percentage points) }\end{array}$ \\
\hline $\begin{array}{l}\text { Argentina } \\
\text { (Greater Buenos Aires) }\end{array}$ & 66.3 & 58.6 & $* 7.7$ \\
\hline Chile & 47.4 & 57.1 & -9.7 \\
\hline Ecuador & 107.6 & 73.4 & +34.2 \\
\hline Mexico & 56.9 & 71.8 & -14.9 \\
\hline Peru ${ }^{a /}$ & 72.4 & 65.3 & +7.1 \\
\hline
\end{tabular}

Source: Author's calculations using data from ECLAC.

Note: Colombia, no data available.

a/ Peru: data from 1997 and 1999.

Monthly income levels for those self-employed, of both sexes, especially women, were low in most countries. Only in Argentina and Chile, for both sexes, and in Mexico, for men, was the level higher. This category accounts for the largest inequalities in men's and women's income, and in every country except Chile, these inequalities were larger than gaps by sex among employers (Table 6). These disparities reflect women's lower average income, associated with the barriers to their access to markets, given their concentration in very saturated and undervalued fields and extensions of domestic labour, along with shorter hours worked, due to the limitations in balancing labour and family responsibilities, or insufficient markets (Table 6).

At the end of the 1990s, this gap was larger than the average for those employed in each country, and largest in Mexico. Income inequality rose during the decade in Colombia, Ecuador and Mexico. Real income for both sexes fell in Colombia and Mexico, although it fell more for women. In Ecuador, in contrast, men retained their income, while women saw it decline slightly.

The income gap between those self-employed fell in Argentina and Chile in the 1990s. In Argentina, this reflected negative trends in real income for both sexes, while in Chile the opposite tendency prevailed.

Table 6: Comparison of self-employed women's share of average monthly income

\begin{tabular}{|l|c|c|c|}
\hline \multicolumn{1}{|c|}{ Countries } & $\mathbf{1 9 9 0}$ & $\mathbf{1 9 9 9}$ & $\begin{array}{c}\text { Change } \\
\text { 1990-1999 } \\
\text { (percentage points) }\end{array}$ \\
\hline $\begin{array}{l}\text { Argentina } \\
\text { Greater Buenos Aires) }\end{array}$ & 51.1 & 60.5 & -9.4 \\
Chile & 55.7 & 67.2 & -11.5 \\
Colombia & 78.5 & 54.1 & +24.4 \\
Ecuador & 56.5 & 52.1 & +4.4 \\
Mexico & 41.8 & 29.7 & +12.1 \\
Peru & 56.5 & 57.1 & -0.6 \\
\hline
\end{tabular}

Source: Author's calculations, using data from ECLAC.

a/ Peru: data from 1997 and 1999. 
Remuneration for wage-earners of both sexes working in microbusinesses was very low, keeping many of them in a perpetual circle of poverty. Wage-earners tend to even out downwards and are the category posting the least income disparity between men and women, with no important differences posted in trends in different countries.

For men it is better to be self-employed than a wage-earner in almost all countries. Retribution for wage-earners is less than for independent workers in every country but Peru. Among women the opposite occurs: wage-earners earn more than self-employed women, except in Argentina and Chile.

The wages of dependent employees in microbusinesses are lower than those with similar educational levels working in small, medium and large firms. These differences are considerable in Ecuador, Peru and Mexico: in the first two countries, remunerations for wage-earners in microbusinesses amount to half those for formal sector employees, while in Mexico they amount to 60\%. In Argentina and Chile, in contrast, the gap shrinks, since workers in micro units receive just over $70 \%$ of those in formal employment. Workers of both sexes with no technical or professional training obtain higher income as independents than as formal wage-earners in both these countries. Something similar occurs with men in Mexico. In contrast, in Peru and Ecuador both sexes and in Mexico women who are not professionals or technicians obtain higher income in private firms with five employees or more.

Trends in gaps by sex among wage-earners in microbusinesses were negative in the 1990s in Argentina and Mexico. In Argentina, women's salaries fell while men's rose, and in Mexico, men's salaries rose more. In the other four countries the gap shrank, although due to other factors. In Chile there was a general increase in wages, particularly women's, and in Ecuador women's wages fell less than men's.

Table 7: Women's share of average monthly income compared to men's in the microbusiness sector

\begin{tabular}{|l|c|c|c|}
\hline \multicolumn{1}{|c|}{ Countries } & $\mathbf{1 9 9 0}$ & $\mathbf{1 9 9 9}$ & $\begin{array}{c}\text { Change in the gap } \\
\mathbf{1 9 9 0 - 1 9 9 9} \\
\text { (percentage points) }\end{array}$ \\
\hline $\begin{array}{l}\text { Argentina } \\
\text { Greater Buenos Aires) }\end{array}$ & 92.1 & 80.0 & +12.1 \\
Chile & 82.1 & 89.1 & -7.0 \\
Ecuador & 83.3 & 88.8 & -5.5 \\
Mexico $^{\text {a/ }}$ & 84.2 & 70.8 & +13.4 \\
Peru $^{\text {b/ }}$ & 69.2 & 86.9 & -17.7 \\
\hline
\end{tabular}

Source: Author's calculations, using data from ECLAC.

Note: Colombia, no data available.

a/ Mexico: data from 1996 and 1999.

b/ Peru: data from 1997 and 1999.

On average, income in the MS is low and falls according to a pyramid in which employers are at the top, followed by independent workers, wage-earners and finally occasional workers. Income levels for the vast majority of those employed in the MS, whether selfemployed or wage-earners, are lower than the average income for those employed in each 
country. Within microbusiness, disparities between the employer segment, on one hand, and independent and wage-earners, on the other, are greater than gender differences. Weller (2000) has underlined that in the 1990s, moreover, the wage gap between microbusinesses and larger firms widened, so internal disparities tended to become more marked.

Owners of microbusinesses or employers, of both sexes, in the six countries, have income higher than the national average. This varies by country, with the best returns almost tripling average national income obtained by men and women, respectively. In the other countries, these do not quite double average income for each sex, and in Peru only men earn slightly more than the national average for men's wages.

These differences among countries also occur for the self-employed and wage-earners, although in the latter's case they are less pronounced and appear as the most homogeneous group, with the most similar behavioural pattern in the region. These last two segments receive very low income in absolute terms; self-employed women earn less than wageearning women in Ecuador, Mexico and Peru, barely above the poverty line there and in Colombia.

Income disparities are more accentuated among women than men. In Argentina, Chile and Ecuador, the largest differences are apparent between female employers and female wage earners, and in Mexico and Peru, the largest distance occurs between the first and selfemployed female workers.

The strongest inequalities occur between female wage-earners and female employers in Mexico, where the wages of the first account for just $17 \%$ of female employers' earnings, followed by Chile (24\%), Argentina (25\%) and Ecuador (34\%), whereas the situation is less unequal in Peru (62\%), mainly reflecting the low relative income of female employers. When the situation of female employers and self-employed workers is compared, wage differences are smaller in Ecuador (self-employed women earn 38\% of female employers' earnings) and Argentina (34\%) and widen in Mexico (where self-employed workers earn barely $14 \%$ of the income obtained by female employers).

Wage-earners' income and that of the self-employed are relatively similar and in no case approach the average for those employed. In every country studied (except Peru, where the opposite is true), self-employed men earn more than wage-earners. Self-employed women workers, meanwhile, earn more than wage-earning women in Argentina and Chile. In other countries, microbusiness wage-earners earn higher wages, probably reflecting longer hours of work.

\subsubsection{Poverty is greatest in the informal sector}

Typically it is argued that there is a direct relationship between belonging to the informal economy and being poor. Formal sector employees tend to have higher wages than those in the informal sector and the incidence of poverty among those formally employed is lower than in the informal sector and the population as a whole. To be in the formal sector, however, does not guarantee that one is no longer poor, since high and low income sectors coexist in that part of the economy. Similarly, not all those employed in the informal sector are poor.

Poverty does not affect all MS employees equally. Its incidence among employers is low. In every country for which data exists, poverty is greater among those working in microbusinesses than among those self-employed. This can be attributed to the low salaries of wage-earners in particular. 
The incidence of poverty among wage-earners' households is very high in Ecuador: more than half those employed receive insufficient income to meet their families' basic needs. This, therefore, is an enormous mass of working poor, suffering from poverty that does not reflect lack of work, but rather insufficient income. This phenomenon, which is very widespread, affects those working in the informal economy to a larger degree than those who are self-employed or wage-earners in microbusinesses (Table 8).

Table 8 : Poverty within the employed population, urban zones, 1999

\begin{tabular}{|c|c|c|c|c|c|}
\hline $\begin{array}{c}\text { Countries/ } \\
\text { years }\end{array}$ & $\begin{array}{c}\text { Total } \\
\text { employed }\end{array}$ & $\begin{array}{l}\text { Private wage- } \\
\text { earners }{ }^{\text {a/ }} \text { in } \\
\text { establishments } \\
\text { employing more } \\
\text { than } 5 \text { people }\end{array}$ & $\begin{array}{l}\text { Private wage- } \\
\text { earners }{ }^{\mathrm{a} /} \text { in } \\
\text { establishments } \\
\text { employing } \\
\text { up to } 5 \text { people }\end{array}$ & $\begin{array}{l}\text { Self-employed } \\
\text { workers in } \\
\text { manufactu- } \\
\text { ring and } \\
\text { construction }\end{array}$ & $\begin{array}{c}\text { Self-employed } \\
\text { workers in } \\
\text { commerce } \\
\text { and services }\end{array}$ \\
\hline $\begin{array}{l}\text { Argentina } \\
\text { (Greater Buenos } \\
\text { Aires) }\end{array}$ & 10 & 9 & 17 & 14 & 8 \\
\hline Chile $1998^{\mathrm{b} /}$ & 14 & 14 & 21 & 11 & 9 \\
\hline Colombia & 38 & -- & -- & 60 & 54 \\
\hline Ecuador & 53 & 55 & 70 & 68 & 62 \\
\hline Mexico 1998 & 31 & 36 & 49 & 39 & 30 \\
\hline
\end{tabular}

Source: Author's calculations, using data from ECLAC.

Note: Peru, no data available.

a/ Excluding professionals and technicians.

b/ In establishments employing more than 5 people, Chile includes public sector wage-earners.

Given the wide range of conditions that characterize microbusinesses and the difficulties in establishing strict working definitions for the sector and informal employment, one way of analysing the link with poverty is through the conditions prevalent in the different occupational categories involved. The first conclusion that stands out in this sense is that there is no direct relationship between working in the MS and being poor. This statement is valid for those self-employed and wage-earners, but not for employers.

To examine the socioeconomic conditions of the three main groups making up the MS, they were ranked according to the income quintile to which their households belong, using all income received by those working in the household as our point of reference. In the six countries studied, the incidence of poverty among microbusiness employers is low. These fit into each country's social structure in a similar fashion and there is a rising curve: a small percentage belong to the poorest quintile of the population, while most of these business people belong to social sectors other than those of the wage-earners they hire, particularly in countries such as Chile. In these conditions, it seems unlikely that most microbusinesses are the result of a transition from independent labour of a precarious nature. Microbusinesses hiring employees require special conditions to overcome difficulties with financing, access to networks and markets, and support from the family and social environment. 
The flattest curve, which reveals the greatest social range, is apparent in Colombia and the steepest is in Chile, where a large percentage of microbusiness employers belong to the country's wealthiest $20 \%$ of households. Peru is the only country of those analysed where the curve moves downward, with most employers fall into the $2^{\text {nd }}$ and $3^{\text {rd }}$ quintiles, indicating they belong to lower income households and experience more poverty compared to other countries (Figure 4).

Figure 4: Employers in the microbusiness sector by family income, 2000

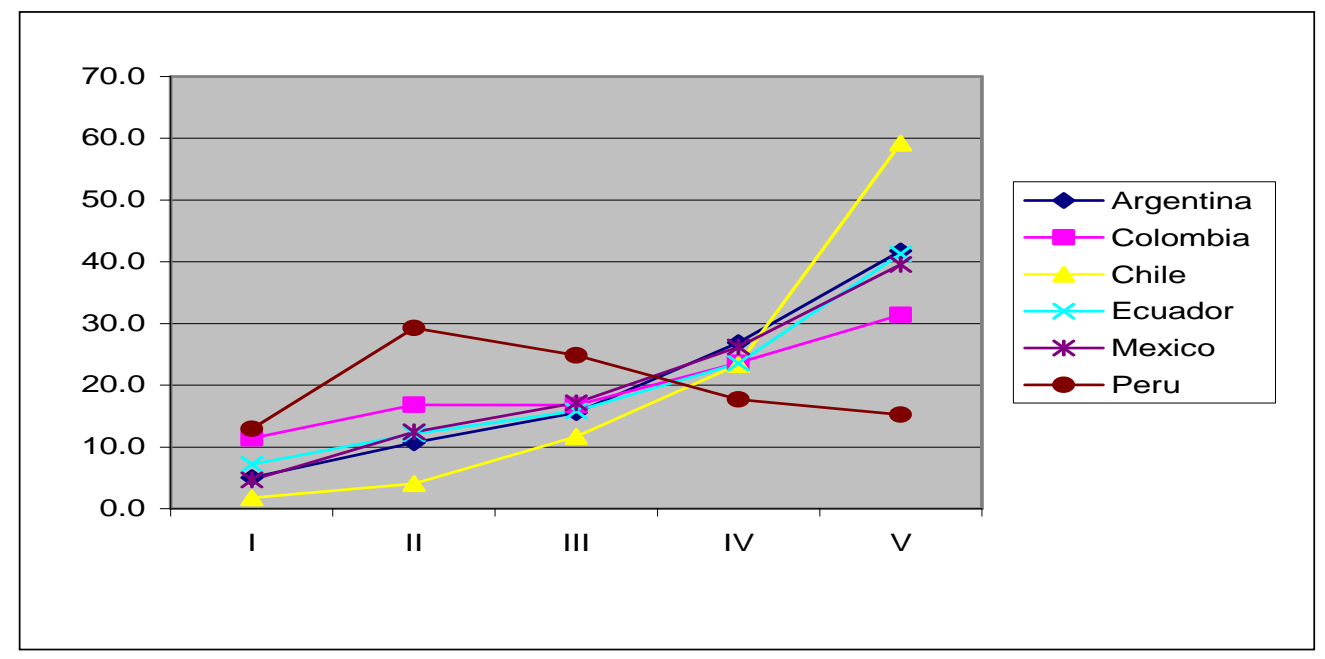

Source: Author's calculations, based on data from the ILO.

In the case of independent workers, the curve is completely different from that of employers: this group is much more heterogeneous. Trends also vary among countries, forming two separate groups with similar behaviour. The first includes Peru, Colombia and Argentina, which post a downward curve, revealing concentration among the poorest households, with less participation from higher income strata. The second consists of the other three countries studied and reveals a smoother curve. In Mexico, the peak occurs at the third income quintile, while in Ecuador and Chile in the fourth. This reveals that independent workers from Mexico, Chile and Ecuador are better off, comparatively speaking, than those in Argentina, Colombia and Peru (Figure 5).

Figure 5: Self-employed workers by family income quintile, 2000

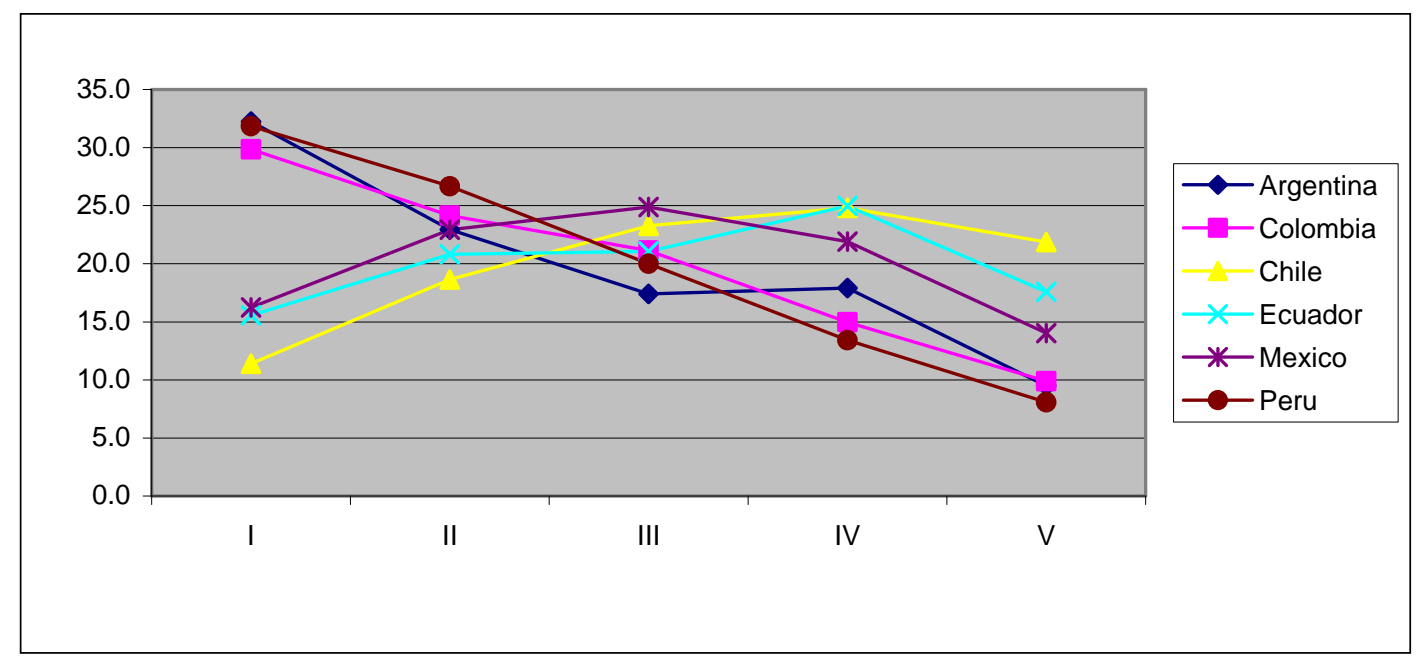

Source: Author's calculations, based on data from the ILO. 
The households to which the self-employed belong are significantly poorer than those of microbusiness employers. A high percentage of those in the first group of countries fall into the first two income quintiles, indicating not only a high incidence of poverty but also their belonging to least favoured strata, probably associated with small-scale operations with little monetary and social capital and little mobility.

Wage-earners post a curve similar to the self-employed, but the differences between countries are less marked. This curve is a little steeper than in the case of the selfemployed, because there are fewer wage-earners in the first and fifth income quintiles, which also reveals less variation within the group (Figure 6).

Figure 6: Microbusiness sector wage-earners by family income quintile, 2000

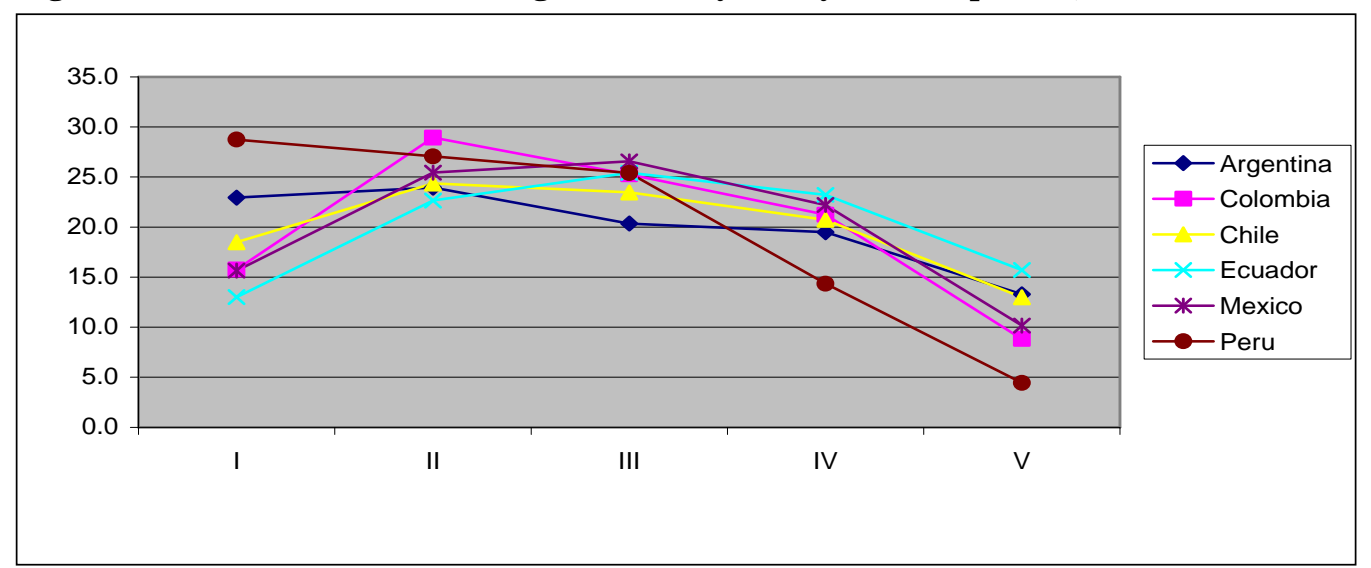

Source: Author's calculations, based on data from the ILO.

Wage-earners are concentrated in the second and third income quintiles and except for Peru and Argentina, their distribution curve is more regular. Peru has the largest number of wage-earners in the first income quintile, reaffirming the precarious conditions experienced by those working in the informal economy.

\subsection{Self-employed women workers: shorter hours than microbusiness employers}

An important aspect of job quality is the length of the working day (and therefore the time available for other activities), since this affects workers' physical and mental health. Legislation establishes a minimum of eight hours per day and 48 hours per week in almost every country in the region. Those self-employed and employers are not covered by this rule. Compared to wage-earners, microbusiness employers tend to work longer hours while those self-employed tend to have shorter working hours.

Men generally work more hours per week. The difference in working hours between the sexes may arise from the supply of employment (more jobs with shorter working hours are available for women) or decisions in which women choose to work shorter hours, to meet their domestic obligations or for other reasons.

In the six countries studied, the hours of work of those self-employed clearly follow a gender-specific pattern: more women work shorter workdays. This may reflect a choice and a strategy for combining wage work with domestic tasks. However, these shorter working hours may be unwanted, reflecting problems such as lack of capital, lack of markets, temporary businesses, all situations that affect women more. About one-third of 
self-employed women work extremely short hours, less than 20 hours per week (except in Mexico, where one in four works this amount), while only a very small number of men work part time (Table 9). At the same time, a high percentage of self-employed women and the largest percentage of men work very long hours, over 49 per week. This difference in the work week explains part of the monthly income gap, but not completely.

Table 9: Distribution of self-employed workers by work week and sex, 2000 Urban areas

\begin{tabular}{|l|c|c|c|c|c|c|}
\hline \multirow{2}{*}{ Country } & \multirow{2}{*}{ Sex } & \multicolumn{6}{|c|}{ Hours of work per week } \\
\cline { 3 - 7 } & & $\mathbf{1 ~ t o ~ 2 0}$ & $\mathbf{2 1}$ to 40 & $\mathbf{4 1}$ to 48 & 49 and over & Total \\
\hline \multirow{2}{*}{ Argentina } & $\mathrm{M}$ & 21.0 & 28.3 & 16.1 & 34.5 & 100.0 \\
& $\mathrm{~W}$ & $\mathbf{3 1 . 6}$ & $\mathbf{2 9 . 1}$ & 10.5 & 28.8 & 100.0 \\
\hline \multirow{3}{*}{ Chile } & $\mathrm{M}$ & 20.4 & 40.2 & 15.4 & 24.0 & 100.0 \\
& $\mathrm{~W}$ & $\mathbf{3 7 . 6}$ & 15.3 & 7.2 & $\mathbf{2 4 . 2}$ & 100.0 \\
\hline \multirow{2}{*}{ Colombia } & $\mathrm{M}$ & 11.3 & 22.8 & 17.9 & 48.0 & 100.0 \\
& $\mathrm{~W}$ & $\mathbf{3 1 . 6}$ & $\mathbf{3 2 . 9}$ & 11.3 & 24.1 & 100.0 \\
\multirow{3}{*}{ Ecuador } & $\mathrm{M}$ & 12.0 & 28.7 & 13.1 & 46.2 & 100.0 \\
& $\mathrm{~W}$ & $\mathbf{3 5 . 8}$ & 28.2 & 7.1 & 28.9 & 100.0 \\
\hline \multirow{2}{*}{ Mexico } & $\mathrm{M}$ & 5.5 & 22.1 & 34.5 & 37.9 & 100.0 \\
& $\mathrm{~W}$ & $\mathbf{2 5 . 0}$ & $\mathbf{2 9 . 1}$ & 19.2 & 26.7 & 100.0 \\
\hline \multirow{2}{*}{ Peru } & $\mathrm{M}$ & 14.7 & 20.9 & 14.7 & 49.7 & 100.0 \\
\cline { 2 - 7 } & $\mathrm{W}$ & $\mathbf{3 8 . 6}$ & 20.1 & 7.4 & 33.9 & 100.0 \\
\hline
\end{tabular}

Source: Author's calculations, based on data from the ILO.

Note: Cases where the percentage of women higher than men are in bold.

The strong differences in the hours worked by independent workers of both sexes do not occur in the case of male and female microbusiness owners, whose patterns of working hours are more similar and, generally speaking, longer, making this the segment working the longest hours per week. ${ }^{19}$ In the MS, the vast majority work more than 49 hours per week, at a far higher rate than the general average for people working these hours in every country. This suggests that survival in these businesses is based on conditions of overexploitation, which involve personal costs and cannot go on indefinitely.

In the six countries analyzed, the commonest work day for men and women microbusiness owners is a lengthy one. Around half of employers of both sexes work more than 49 hours per week. Mexico is the exception, with just one-third of women working these lengthy hours and a similar percentage working less, from 21 to 40 hours per week (Table 10).

Unlike independent workers, very few business women work less than half-time (20 hours per week). Only in Ecuador and Chile is this group significant.

\footnotetext{
${ }^{19}$ In Latin America overall, just over one-fifth of those employed (both sexes) work these hours.
} 
Table 10 : Distribution of microbusiness sector employers by hours of work per week and sex,

\section{Urban areas}

\begin{tabular}{|l|c|c|c|c|c|c|}
\hline \multirow{2}{*}{ Country } & \multirow{2}{*}{ Sex } & \multicolumn{5}{|c|}{ Employers' hours of work per week } \\
\cline { 3 - 7 } & & $\mathbf{1}$ to $\mathbf{2 0}$ & $\mathbf{2 1 ~ t o} \mathbf{4 0}$ & $\mathbf{4 1}$ to 48 & $\mathbf{4 9}$ and over & Total \\
\hline \multirow{2}{*}{ Argentina } & $\mathrm{M}$ & 2.3 & 18.3 & 20.4 & 59.1 & 100.0 \\
& $\mathrm{~W}$ & $\mathbf{3 . 8}$ & $\mathbf{2 6 . 0}$ & 11.2 & 59.1 & 100.0 \\
\hline \multirow{2}{*}{ Chile } & $\mathrm{M}$ & 11.5 & 13.5 & 16.3 & 58.7 & 100.0 \\
& $\mathrm{~W}$ & $\mathbf{1 6 . 5}$ & $\mathbf{1 7 . 9}$ & 12.3 & 53.3 & 100.0 \\
\hline \multirow{2}{*}{ Colombia } & $\mathrm{M}$ & 3.4 & 12.3 & 26.0 & 58.3 & 100.0 \\
& $\mathrm{~W}$ & 5.9 & $\mathbf{1 5 . 4}$ & 22.4 & 56.3 & 100.0 \\
\hline \multirow{2}{*}{ Ecuador } & $\mathrm{M}$ & 3.7 & 27.3 & 16.7 & 52.3 & 100.0 \\
& $\mathrm{~W}$ & $\mathbf{1 9 . 7}$ & 24.1 & 8.1 & 48.1 & 100.0 \\
\hline \multirow{2}{*}{ Mexico } & $\mathrm{M}$ & 1.3 & 12.1 & 40.8 & 45.8 & 100.0 \\
& $\mathrm{~W}$ & $\mathbf{8 . 0}$ & $\mathbf{3 2 . 2}$ & 28.6 & 31.2 & 100.0 \\
\hline \multirow{2}{*}{ Peru } & $\mathrm{M}$ & 6.2 & 20.1 & 14.4 & 59.4 & 100.0 \\
& $\mathrm{~W}$ & 0.0 & 2.9 & $\mathbf{2 1 . 7}$ & $\mathbf{7 5 . 4}$ & 100.0 \\
\hline
\end{tabular}

Source: Author's calculations, based on data from the ILO.

Note: Cases where the percentage of women higher than men is in bold.

Although the percentage of women business people working very long hours is rather high, the percentage of men doing so is larger is every country but Peru, where there are more women than men in this situation. Nonetheless, women's income is still lower. 


\section{Conclusions}

This study has examined the dynamics and behaviour of an important segment of the informal economy, the microenterprise sector (MS), during the 1990s, in the context of the major changes affecting the world's economy during this period. The decade has brought the expansion of market globalization, bringing with it an unprecedented and rapid opening of countries to trade and finance and the predominance of capitalism in most of the world, along with important technological progress, particularly in communications and information, and their combination in the Internet. ${ }^{20}$

The countries of Latin America have participated in this process, which coincided with the ending of military dictatorships and authoritarian regimes. The region's new democracies have implemented or continued with liberal reforms. Most have, to varying degrees, cut tariffs, adopted export-based policies, reduced their public sectors, privatized services and made their labour markets more flexible, but in general the results have not been satisfactory. Despite recovering GDP growth rates and exports in the 1990s, the decline in average inflation and the resumption of foreign credit flows, attracted by privatizations at low prices after they dried up during the "lost decade" of the 1980s, a crisis that can be attributed to excessive borrowing abroad, the social and labour results of these reforms have been unsatisfactory so far during the $21^{\text {st }}$ century. Indicators confirm that poverty has barely been contained, while unemployment, under-employment and informality rose throughout the region in the past decade. At the same time, income distribution, long considered the worst in the world, did not improve or grew even worse.

In this context, the MS has played an important role as a source of family income and employment, especially for workers of both sexes from poor households. Overall, the informal economy expanded during the 1980s, offering "refuge" to workers expelled from the formal sector, who either lost their jobs due to restructuring and/or the privatization of companies, or due to the bankruptcy of whole sectors that could not withstand the more open economies or the crisis that hit in the 1990s.

For sectors with better skills and education, access to networks and negotiating capacity, microbusinesses have offered a way to make the most of new opportunities for economic integration, allowing them to participate in the decentralization of production in more advantageous conditions and with more formality. A few microbusinesses of variable sizes have reaped the benefits of globalization, because they have managed to link into national and international productive chains, receiving technology and access to more markets, and thereby gaining in competitiveness, income and modernity. This segment is formed by the more educated groups, which function within the logic of the economy and are able to set up microbusinesses and generate jobs on a small scale. It is likely that as these consolidate they will become increasingly part of the formal business sector.

In contrast, most of the MS operates under very precarious conditions, with little access to sources of financing, capital and technology, in a logic dominated by survival rather than the possibilities for accumulating wealth. This segment accounts for the majority in all six countries, although its importance varies, and is linked to the global economy but without winning the benefits necessary to escape from its own marginality. Typical of this segment are street vendors who sell imports, most of whom have little education, are very poor, operate on a very small scale and through different forms of self-employment. Their situation is ambivalent: they are in the system, but not of it.

\footnotetext{
${ }^{20}$ For an analysis of the social dimensions of globalization, see ILO, 2004b.
} 
The countries with the most numerous microbusinesses are also those where the sector is most precarious and survival its main purpose. With productive structures that are weak or strongly affected by the opening of their economies (especially Colombia), the MS offers refuge to workers who join the labour force or have been displaced from larger firms and lack the skills, capital and contacts necessary to generate their own employment. In these cases, the MS is their last chance to survive poverty.

The wide range of business types is apparent in countries with larger domestic markets and more consolidated productive structures and smaller ones alike. The results confirm growing internal polarization, but at the same time the differences between countries have also grown. Mexico, for example, has the MS segment that has benefited the most from the more open economy and particularly rising exports under the Free Trade Agreement with the United States and Canada, while another segment remains at the survival level, with solid economic results apparent. In Argentina, one of the region's countries with a large domestic market, not only has the economy performed poorly but, due to internal imbalances and the turnaround in capital flows, it became mired in its worst crisis in recent decades, in 2002. In Chile, a small economy in Latin America, the MS, although smaller, has benefited more than in other countries from international investment flows and economic growth in the 1990s, while Ecuador, another small-scale economy, ended up plunged into a substantial recession amidst a steep rise in income concentration.

Microbusinesses reproduce the gender inequalities apparent in society as a whole and in the rest of the economy. Gender gaps are apparent in women's under-representation in the MS, and within it, in their concentration in the most precarious jobs, involving selfemployment. With little ability to save and in general lacking property registered in their names that would give them access to starting credit, women begin their businesses with a minimum capital base, which limits the scale of their operations and access to the machinery that could improve productivity. They are concentrated in a few productive areas, which are already saturated and highly competitive, whose main advantage is that they allow women to work and fulfil their domestic responsibilities, but leaves them earning less and accumulating little. Income gaps between men and women are significant in every country. In the countries where the MS is characterized by precariousness and informality, women's conditions tend to be worse than in others where these conditions do not prevail.

This study has revealed the precariousness of the available data and the need to analyze gender disparities. Perhaps the first priority should be specifically to generate data differentiated by sex on the situation facing the MS and capture new information about relevant aspects, to facilitate recognition of gender disadvantages, which would make it easier to design policies in support of microbusinesses that include the objective of improving opportunities open to women. Often policies and programmes do not recognize the differences and limitations affecting men and women in the MS, so interventions fail to focus on the specific roles and needs of each gender.

A second fundamental conclusion is that a "gender gap" remains pending, which involves recognizing and valuing the contribution made by women in the MS to overcoming poverty, along with their decisive role in generating employment and wealth. The "payback" of this debt, which should be assumed by governments and social actors, requires recognizing the disadvantages and discrimination that hinders women, and generating corrective measures that tend to create not only equal opportunities, but also equal results. The challenge is to generate policies that not only situate women as passive receivers of social assistance but also as economic actors and subjects with rights. Policies should promote women's entrepreneurial development by dealing with gender inequalities. If they fail to do so, they could simply increase the burden of work without improving their control over the income thus generated. Given the wide range of women in microbusinesses, public responses must consider these realities and respond to the needs of 
different types of business, according to a set of factors that includes skills and qualifications, women's motives and expectations, family conditions, scheduling possibilities, the nature and organization of microbusinesses, their growth potential, and the economic conditions and business environment necessary for this. The goal of empowering women should be present in ever intervention and interventions must include a component that allows them to become aware of how decision making at the broadest level affects their business, giving them the skills to influence their environment.

To ensure that women heading microbusinesses benefit from programmes to support the sector, it is vital that from the design stage onward, the sexual division of labour and women's double role be taken into consideration. Interventions that achieve the goal of generating more income generally involve overwork, since their work day must be added to the hours they spend on their domestic tasks. Any failure to take this into consideration could lead to the failure of initiatives that aim to increase labour productivity. There are women who, faced with this choice, prefer to remain in less profitable activities that nonetheless allow them to dedicate more time to family and domestic activities. Thus, the right basic infrastructure to deal with child care and support domestic tasks is vital. The potential impact of technological interventions that help to reduce domestic tasks assumed by those working in microbusinesses should be explored more carefully and women should be consulted on their own priorities and strategies for what should be included in defining actions to be undertaken.

Third, policies should include among the requirements to receive support the achievement of real improvements in the working conditions of all those involved in the MS. This means that policies must also consider the self-employed, employers, wage-earners and unremunerated family members. Their inclusion will lead to a redistributive effect within the MS, in favour of those who are poorest and most vulnerable.

Fourth, the regulatory environment of the MS should be reviewed to facilitate the development of different types of microbusinesses and family businesses. Particularly important is an approach that gives priority to inclusion, rather than compliance with obligations, through sanctions and without prior recognition of rights. This issue has recently been explored by Reinecke and White (2003), who underline the importance of a legal and regulatory environment suitable to the needs of the MS. Tokman (2001), for his part, proposes measures such as recognizing informal ownership to facilitate access to financial credit, labour relations to ensure protection, and links with national and municipal authorities.

Improving access to technological information is also relevant, including training and obtaining appropriate machinery and supplies. In this sense, shortages are greater among women than men in the MS. However, technology should be adapted to the way that small economic units work and cannot simply be transferred without this process taking place beforehand. Something that is useful to a multinational may not be useful for small microbusinesses, for example.

It is also necessary to review credit policies to broaden women's access to credit and thereby improve distribution of property rights. Providing access to credit in general, but particularly for women, is considered a condition for relieving poverty and giving them more decision-making powers. The first challenge is to ensure women have more access to formal credit, overcoming barriers of supply and demand, associated with household poverty and the precariousness of their businesses, as well as cultural factors arising from their gender. Moreover, inequalities facing those who have gained access to credit, in terms of duration, amounts requested and granted, guarantees required, and interest rates, must also be corrected. It should be recognized, moreover, that access to credit alone will not resolve all the problems facing microbusinesses, especially the most precarious. The 
financial component must be complemented by access to new markets, ways of improving product and service quality, and increase business productivity.

The lack of social security for wage-earners, independents and employers of both sexes within the MS, points to a seventh, urgent task, that of generating mechanisms for protecting workers against contingencies that prevent their working due to illness, maternity or ageing. The cost to the State of designing and maintaining these mechanisms is minor compared to future costs of looking after a large contingent of workers who must have pensions and have been unable to save enough, or anything, as occurs now in most microbusinesses.

A final concern, no less important, is the need to foster associations, organization and the creation of networks within the MS. If the sector's knowledge can be improved, public opinion will pay more attention and provide more support, making it easier for this sector to develop negotiating powers within the agenda, as the first step to speaking out on behalf of its own interests to other social and political actors. This is the way to empower women in the MS, as well as improving gender, economic and social equity. 


\section{Bibliography}

Abramo, L. and Valenzuela, M.E. 2001 América Latina: Brechas de equidad y progreso laboral de las mujeres en los 90 (Lima, ILO).

Anker, R. 1998 Gender and jobs. Sex segregation and occupations in the world (Geneva, ILO).

Bangasser, P. 2000 The ILO and the informal sector: An Institutional History (Geneva, ILO).

Benería, L. 2003 Gender, Development and Globalization (New York \& London, Routledge).

ECLAC, 2001 Panorama Social de América Latina 2000-2001 (Santiago, ECLAC). (2002) Panorama Social de América Latina 2001-2002 (Santiago, ECLAC).

Cortés, R. 2003 Mercado de trabajo y género. El caso argentino 1994-2002, in M.E. Valenzuela (ed.) Mujeres, pobreza y mercado de trabajo. Argentina y Paraguay, (Santiago, ILO).

Chávez, E. 2001 La legislación laboral y su impacto en la microempresa: análisis comparativo entre países y propuestas de acción, in V. Tokman (ed.) De la informalidad a la modernidad (Santiago, ILO).

Chen, M., Jhabvala, R. and Lund, F. 2002 Supporting workers in the informal economy: A policy framework (Geneva, ILO).

De Soto, H. 1987 El otro sendero (México, Instituto Libertad y Democracia).

Gálvez, T. 2002 Discriminación de género en el mercado laboral: La brecha de ingresos 2001. América Latina y el Caribe, unpublished consultants' report to the ILO.

Hussmanns, R. 2001 Informal sector and informal employment: Elements of a conceptual framework (Geneva, ILO).

Jacobsen, J. 1998 The economics of gender (Malden, Massachusetts, Blackwell).

Klein, E. and Tokman V. E. (eds.) 1996 Regulations and the informal economy: Microenterprises in Chile, Ecuador and Jamaica (Boulder, Lynne Rienner Publishers).

Marlow, S. 2002 Women and self-employment. A part of or apart from theoretical construct? in The International Journal of Entrepreneurship and Innovation Vol. 3, No.2.

Mirchandani, K. 1999 Feminist insight on gendered work: new directions in research on women and entrepreneurship, in Gender, Work and Organization, Vol.6, No.4.

ILO, 2004a Panorama Laboral 2003. América Latina y el Caribe (Lima, ILO). 2004b Por una globalización justa. Crear oportunidades para todos (Geneva, ILO) 2002a Panorama Laboral 2002. América Latina y el Caribe (Lima, ILO).

2002b El trabajo decente y la economía informal. Informe VI de la Conferencia Internacional del Trabajo, $90^{\circ}$ reunión 2002 (Geneva, ILO).

2001 Panorama Laboral 2001. América Latina y el Caribe (Lima, ILO).

ECLAC, 2004 Panorama Social de América Latina 2002-2003 (Santiago, ECLAC).

Portes, A.; Castells, M. and Benton, L. 2002 The informal economy (Baltimore, The John Hopkins University Press).

Reinecke, G. and White, S. 2003 Policies for small enterprises (Geneva, ILO).

Roffey, B.; Stanger, A.; Forsaith, D.; McInnes, E.; Petrone, F.; Symes, C. and Xydias, M. 1996 Women in small business: A review of research, report by Flinders University of South Australia to the Department of Industry, Science and Tourism, Australia, Canberra.

Schneider, F. 2002 Size and measurement of the informal economy in 110 countries around the world, paper presented at the Workshop of Australian National Tax Center ANU, Canberra, Australia, July 17, 2003.

Stallings, B. and Peres, W. 2000 Crecimiento, empleo y equidad. El impacto de las reformas económicas en América latina y el Caribe (Santiago, ECLAC/Fondo de Cultura Económica). 
Stanger, A; Roffey, B.; Forsaith, D.; McInnes, E.; Petrone, F.; Symes, C. and Xydias, M. 2002 Gender differences in small business owners-management, in the International Journal of Entrepreneurship and Innovation Vol.3, No.2.

Thomas, J. 2002 Decent work in the informal sector: Latin America, (Geneva, ILO).

Tokman, V. 2004 Una voz en el camino. Empleo y equidad en América Latina: 40 años de búsqueda (Santiago, Fondo de Cultura Económica).

2001 De la informalidad a la modernidad, in V. Tokman (ed.) De la informalidad a la modernidad (Santiago, ILO).

(ed.) 1992 Beyond regulations: The informal economy in Latin America (Boulder, Lynne Rienner Publishers).

Tomei, M. 1999 El trabajo a domicilio en países seleccionados de América Latina: Una visión comparativa, Documento de discusión No.29, Development Policy Services Department (Geneva, ILO).

Trejos, J. D. 2001 El trabajo decente y el sector informal en los países del istmo centroamericano, preliminary paper (San José, ETM-ILO).

Valenzuela, M. E. and Venegas, S. 2001 Mitos y realidad de la microempresa en Chile Un análisis de género (Santiago, Centro de Estudios de la Mujer, CEM).

Valenzuela, M. E.; Márquez, F. and Venegas, S. 2001 "Construyendo microempresa en Chile: Trayectorias laborales de hombres y mujeres”, Revista Latinoamericana de Estudios del Trabajo, Year 7, $\mathrm{N}^{\circ} 13$ (Buenos Aires, Alast).

Weller, J. 2000 Reformas económicas, crecimiento y empleo. Los mercados de trabajo en América Latina y el Caribe (Santiago, ECLAC/Fondo de Cultura Económica). 


\section{Policy Integration Department Working Papers}

No. 1 ILO activities on the social dimension of globalization: Synthesis report

No. 2 Measuring decent work with statistical indicators

Richard Anker, Igor Chernyshev, Philippe Egger, Farhad Mehran and Joseph Ritter

No. 3 Globalization and decent work: Options for Panama Philippe Egger

No. 4 Globalización y trabajo decente: Opciones para Panamá Philippe Egger

No. 5 Indicators of social dialogue: Concepts and measurements Lane Kenworthy and Bernhard Kittel

No. 6 Assessing the impact of the attacks of 11 September 2001 on women's employment in the United States

Gertrude Schaffner Goldberg and Helen Lachs Ginsburg

No. 7 Decent work and the informal economy in Central America Juan Diego Trejos Solórzano and Miguel Del Cid

No. 8 Poverty initiatives in the ILO: A review of past and present approaches Pat Holden and Dagmar Walter

No. 9 Whither the International Standard Classification of Occupations (ISCO-88)? Debbie Budlender

No. 10 Improving occupational classifications as tools for describing labour markets: A summary of recent national experiences Debbie Budlender

No. 11 Recent developments in China's labour economy Thomas G. Rawski

No. 12 The Impact of economic liberalization on employment and wages in India Sonia Bhalotra

No. 13 The impact of trade liberalization upon inequality in developing countries Donald J. Robbins

No. 14 The impact of liberalization and globalization on income inequality in developing and transitional economies Giovanni Andrea Cornia

No. 15 The impact of technology transfer on employment and income distribution in developing countries: A survey of theoretical models and empirical studies Mariacristina Piva 


\section{Policy Integration Department Working Papers \\ Prepared by the World Commission on the \\ Social Dimension of Globalization}

No. 16 International finance: Meeting the needs of people in developing countries José Guilherme Almeida dos Reis

No. 17 The gender dimensions of globalization of production Stephanie Barrientos, Naila Kabeer and Naomi Hossain

No. 18 Social exclusion in the context of globalization - Jan Breman

No. 19 Gender and globalization: A macroeconomic perspective Çağatay Nilüfer and Ertük Korkurt

No. 20 Globalization, social exclusion, and work: with special reference to informal employment and gender - Marilyn Carr and Martha Chen

No. 21 Resources for social development - Antony Clunies Ross

No. 22 Does the new international trade regime leave room for industrialization policies in the middle-income countries? - Alisa DiCaprio and Alice Amsden

No. 23 Social dimension of globalization in Latin America: Lessons from Bolivia and Chile, Ivaro García Hurtado

No. 24 The social dimension of globalization: a review of the literature Bernhard Gunter and Rolph van der Hoeven

No. 25 The social dimension of global production systems: A review of the issues, Susan Hayter

No. 26 Reforming global economic and social governance: a critical review of recent programmatic thinking - Jeremy Heimans

No. 27 Corporate social responsibility: an issues paper - Michael Hopkins

No. $28 \quad$ Upgrading in global value chains - John Humphrey

No. 29 Implications of globalization and economic restructuring for skills development in Sub-Saharan Africa - Richard K. Johanson

No. 30 The outcome and impact of the main international commissions on development issues Frédéric Lapeyre

No. 31 Globalization and structural adjustment as a development tool - Frédéric Lapeyre

No. 32 Globalization and perceptions of social inequality - Malte Luebker

No. 33 The changing structure of international trade linked to global production systems: what are the policy implications? - William Milberg

No. 34 Corporate social responsibility: an overview of principles and practice,Jill Murray

No. 35 Inclusive development strategy in an era of globalization - Ignacy Sachs

No. 36 Social consequences of the globalization of the media and communication sector: some strategic considerations - Seán Ó. Siochrú

No. 37 Globalization, history and international migration: a view from Latin America Andrés Solimano

No. 38 Towards a different kind of globalization, or how the anti-globalists view the world Gijsbert van Liemt 


\section{Policy Integration Department Working Papers}

No. 39 How do trade union rights affect trade competitiveness?

David Kucera and Ritash Sarna

No. 40 Statistics on the employment situation of people with disabilities:

A compendium of national methodologies

ILO Bureau of Statistics in collaboration with the In Focus Programme on Skills, Knowledge and Employability

No. 41 Employment in the informal economy in the Republic of Moldova ILO Bureau of Statistics in collaboration with the Department for Statistics and Sociology of the Republic of Moldova

No. 42 Decent work in a least developed country: A critical assessment of the Ethiopia PRSP Graeme J. Buckley

No. 43 Unemployment and Labour Market Institutions:

The Failure of the Empirical Case for Deregulation

Dean Baker, Andrew Glyn, David Howell and John Schmitt

No. 44 Women's access to occupations with authority, influence and decision-making power: Women as legislators, senior officials and managers around the world Richard Anker.

No. 45 The world of work in the context of economic integration and trade liberalization Daniel Martínez

No. 46 Poverty reduction in Pakistan: The strategic impact of macro and employment policies Moazam Mahmood

No. 47 Trends in Work Stoppages: A Global Perspective L. J. Perry and Patrick J. Wilson

No. 48 Generating decent work for poverty reduction in Cambodia: The voice of workers, employers and the Government Moazam Mahmood

No. 49 The Social Dimension of Regional Integration in ECOWAS René Robert

No. 50 Measuring trade union rights: A country-level indicator constructed from coding violations recorded in textual sources David Kucera

No. 51 Patterns of job quality attributes in European Union Joseph A. Ritter

No. 52 Child Labour, Education and Export Performance David Kucera and Ritash Sarna 
No. 53 Measuring the informal economy: From employment in the informal sector to informal employment

Ralf Hussmanns

No. 54 Indicators of labour standards: an overview and comparison

Richard N. Block

No. 55 The pattern of globalization and some implications for the pursuit of social goals Gerry Rodgers

No. 56 Statistical indicators of social dialogue: A compilation of multiple country databases Anne Chataigner

No. 57 Trade unions and informal workers' associations in the urban informal economy of Ecuador - Catherine Vaillancourt-Laflamme

No. 58 Decent work, standards and indicators

Monique Zarka-Martres and Monique Guichard-Kelly

No. 59 Social Dialogue Indicators: Trade Union Membership and Collective Bargaining Coverage, Statistical Concepts, Methods and Findings

Sophia Lawrence and Junko Ishikawa

No. 60 Informality and Gender in Latin America

María Elena Valenzuela 